\section{座長のまとめ}

\section{渡辺 岩雄}

36席は乳癌に腫瘤を触れず，しかも異常分泌を認めな い潜在性乳癌についての報告であるが，腋窩転移リンパ 節を触知し，しかも原発巣が乳癌である可能性は60〜70 \%であることを考えれば演者の報告のごとくこのような 臨床像を示した場合には積極的炕乳房切断術の適応と考 えるのが妥当であるら.

$37 ， 38$ 席は若年者乳癌についての報告であるが，若年 者と一括称しても，10歳代と20３5歳代とでは病因論的 に腺腫之の関係，生理的・内分泌的環境あるいは病期な ど必ずしる同一病態として画一的には論じられないと思 う. 従ってより年㱓層を別けて検討すればこれら年龄層 の臨床的特異性が明らかにされるかる知れない。

阪市大酒并教授から患者本人に対し手術をどのように して納得了解させたらよいかという問題提起があった。 確か儿二次性徵としての乳房を切断するといら心理的・ 肉体的要素は他の年龄層之は異なって思春期前後の乳癌 においてはまた格別な意義をるっていることは見逃せな
W.

39席では男子乳癌について診断面での遅れ，進行性の 経過をたどることなどが述べられた。

教室で最近経験した男子乳癌例では術前血中 estradiol が高值を示し, 術後正常域に復ししかる術前みられなか った下垂体 gonadotropin 分泌の元進状態がみられるな ど乳癌組織自体が estradiol 産生腫煌であることを示唆 する成績を得ているので追加したが，今後男子乳癌につ いても内分泌的な面からの検討が必要となってこよう.

40，41席は乳癌と他藏器癌との重複癌についての報告

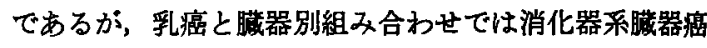
とりわけ胃癌，大腸癌との併存が多いが，一方子宮䫟 癌, 卵巣癌あるいは甲状腺癌など内分泌系脏器癌との組 み合わせも可成り頻度を占めている.これについては単 なる癌の発生頻度による偶然の併存に過ぎないとの見解 であったが，統計的数値よりみると何らかの共通の内分 泌的因子の関与む想定され，この面からの解析に興味か もたれる。

\title{
第IV会場 午前の部
}

胸部 I (IV-1 5) 夾長 小松 作藏

IV-1. 漏斗胸の外科 札幌医科大学第 2 外科 草耇 膳之

抄録号参照

IV-2. 亜症筋無力症に対する 胸腺摘除術の効果につ いて

岡山大学第 2 外科

由中 聰, 谷崎 真行, 戸田 完治
大塚 昭雄, 塩田 邦彦, 東 良平
寺本 滋

岡山大学第二外科で胸腺摘除を施行した重症筋無力症 患者は, 男13例, 女24例の37例で, 前者に 5 例, 後者に 9 例の胸腺腫合併例があった. 手術時の年龄は30歳未満 9 例，30歳以上28例で，胸腺腫合併例は 1 例をのぞきす へて30歳以上であった，発症から胸腺摘除までの期間 は, 約半数で 3 年末満 $(1$ 年末満 10 例, 万ち胸腺腫合併 例 9 例) であったが，10年以上のものが8例あった。手 術死は, 術後11日目に失った漫潤型胸腺腫の 1 例のみで あった。

胸腺摘除後 2 カ月まで認められた近接効果では，胸 腺腫非合併例 ( I 群) の寛解率は40\%, 著明改善率は30 $\%$ ，胸腺腫合併例（II 群）のそれは，それぞれ50\%，21
\%で，両者をあわせた症状改善率は，I 群，II群とすに 約70\%で，差違は認められなかった．また女性の改善率 がやや高率であった涪かには，各群とむに，年龄，有症 期間, 病型による効果の差違はとくに認められなかっ た.

しかしながら，胸腺摘除後 3 年以降の遠谝効果につい てみると、I群とII群の間には明らかな差違があり，寛 解率はI群で38\%であるのに対し，II群では $8 \%$ にすぎ ず，抗アセチルコリン戍を必要としない著明改善例も， I 群では29\%にみられたが，II群では 8\%にすぎなかっ た。寛解を合む症状改善率す，I 群て72\%，II 群で41\% であって, 胸腺腫合併の有無は遠隔効果を左右する最も 重要な因子であった。な扰近接効果において症状改善の みられなかったものでも，䄪半数では 1 年ないし 3 年後 に完全寛解が得られていたか，胸腺腫合併例にはみられ なかった。

30例について, 胸腺内の肧中心形成度と遠隔効果の関 連を調查したが，I 群では形成度の高いものの方が, 低 いものに較ぺて症状改善率が高かったが，II 群では肧中 心形成度の違いによる効果の差違は認められなかった。

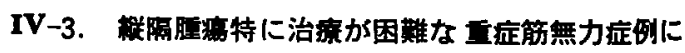
गढर 
横浜市立大学第 1 外科

城島 標雄, 井出 小児精神神経科

研, 五島 英廸 吉沢 勇

昭和39年より14年間に当科にて手術した綎隔疾患は40 例である.そのうち14例が胸腺によるるのであった。 た重症筋無力症の合併は 4 例で悪性 1 例, 良性 1 例, 胸 腺のみ 2 例であった.この合併例 4 例について述べる.

症例1. 45歳, 兵重症筋無力症発症後 3 力月して良 性胸腺摘出したが不充分なる呼吸管理のため 2 カで死 亡した。

症例2. 37藏早 ${ }^{\prime}$ 重症筋無力症発症後, 薬物療法, 放 射線療法を行 5 む改善せず， 6 年後胸腺摘出，術後症状 軽仭し現在経過観察中である。

症例3. 46歳古重症筋無力症発症後 1 年して胸腺腫 瘍摘出術を試みるも悪性胸腺腫のため摘出不能, 生検に 终る.術後放射線治療を行ない一時症状の改善もみられ たが肺合併症のため 4 カ月で死亡した。

症例4. 32 歳古 昭和 43 年上肢挙上困難, 眼球運動不 良, 噮下障害, 呼吸困難出現, 重症筇無力症の診断にて 抗コリンェステラーゼ刘投与により呼吸困難は消失する 他の症状の改善はみられなかった。昭和46年胸腺に放 射線治療を行うも改善されず，昭和52年10月17日胸腺摘 出術施行した。術後自発呼吸, 困難のため人工呼吸器使 用，術後10日目に自発呼吸可能となりまた筋力るかなり 改善されたが燕下障害は全く改善せず，その後呼吸障害 及び蕉下障害は除々に悪化, 更に肺合併症む加わり10カ 月後死亡した。

以上 4 例のらち症例 2 は症状の改善した例ですが症例 4は手術により増悪した例であります．これは従来の重 症筋無力症の症状が単に進行したものか，あるいは手術 が原因で呼吸障害, 嚥下障害が固定したものか不明であ ๖.

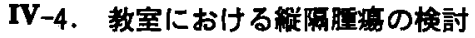 札幌医大第 2 外科 \\ 庭瀬 公武, 高田 憲一, 草島 勝之 杉木 健司, 長谷川恒彦，須田 義雄 小松 作藏}

1956年より1978年 7 月まで23年間に教室で行った緥隔腫 痬手術例は101例である。この内悪性例は，成人群で 4 例，5.7\%であり，小児では 4 例，13\%である.成人例 中胸腺の悪性カルシノイドは術後 2 年又, 線維肉腫例は 術後 1 年で生存中であるが, 悪性胸腺腫例は術後 6 力 月, 又心の5由来の未分化癌例は, 術後 1 カ月で死亡し
た. 小児例中覀性奇形隀の 1 例は術後 4 年神経節芽腫は 很後 7 年で生存中であるが， 2 例の悪性胸腫湯は，いつ れる術後 6 力月以内に死亡した．成人の良性腫湯として は，奇形腫神経原腫湟，胸腺腫場の順に多い，重症筋無 力症は 7 例あり，手術後寛快をみたのは 3 例である。小 児の良性腫榎中, Cervicomediastinal Cystic Hygroma は 2 例共呼吸困難をきたし，㗨急手術を必要とした。小児 では，压迫による気管閉塞を起こしやすい為，早期手術 が望まれる. 診断には，従来の検查法に加え CT スキャ ソ，超音波検査により，正確度を增した。

この内診断，治療上興味のあった 4 例を報告する。 1 例目は41歳男性で無症状であったが後縱隔腫瘍像を X$\mathrm{P}$ 上認めこれは CT スキャンでも確認された。しか し経過観察中に，腫瘍像は完全消失し，特発性炎症であ ったと思われる，2例目は，左胸腔内に突出した瘇瘍 で, 術前, 心室造影, 冠動脈造影により，心外腫瘍の診 断であったが，仮心室瘤であった３例目は，71歳男性 で, 呼吸困難, 上大静脈症候群を呈した例で，術中心襄 内原発とみられる末分化癌であった４例目は，65歳男 性で，13年前より胸部異常所見を指摘され，4年前より 変化はみられず，良性綎隔腫瘍と思われたが，病態学的 には, 線維肉腫であった。

\section{IV-5. 自然気胸症例の検討} 東邦大学第 1 外科

$$
\begin{aligned}
& \text { 太田実, 佐々木 } \text { 忠 } \\
& \text { 柳沢 正弘, 加藤 治 }
\end{aligned}
$$

近年, 自然気胸症例は増加の傾向を示しているが，当 科に括いても外科治療総数28症例の5ちで過去 3 年間で 19例を経験した．過去 3 年で手術を施行した割合は31.6 \%であった，部位別では左側18例，右側10例と左側に多 く，年齢別では20歳代がピークであり，性別では男子に 圧倒的に多かった。また症例のほとんどは身長が比較的 高くやせ型に属していた．手術例の入院時肺虚脱度では $20 \%$ 30\%が最も多く平均虚脱度は $42.7 \%$, 保存症例の それは 40.5\%と有意の差はなかった。初発症状の多くは 胸痛・呼吸困難であり，症例の85\%は，初回から過去 2 回の既往回数であった．手術症例の入院から手術までの 間の治療をみるとドレーン挿入が75\%を占め，入院時の 合併症としては，血胸 2 例，他側気胸 2 例, 気管支喘息, 肺結核があった，外科療法の理由としては，短期間再 発, 長期肺虚脱, 運期間再発の順に多かった. 手術方法 としては，ブラ縫縮 15 例，ブラ部分切除12例，上葉切除 1 例を施行した．上葉切除を施行した症例は巨大萃胞を゙ 
有した症例であったた．また我々の行っている手術方針 としては, 腋窝切開, 第 3 肋間又は 4 助間開胸後, Air Leakage 確認しブラの所見によりすなわち巨大ブラ や Stiel を持っているブラではブラ切除か部分切除を, 小さなブラか限局性多発ブラは程縮術を考虑します．次

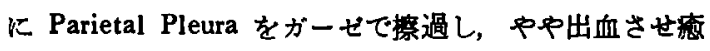
着促進をはかり，抗生剤投与後，トレーン㨉入し閉胸す る.

\section{座長のまとめ}

小松 作藏

学会第一日目第 $\mathrm{V}$ 会場午前の部は, 胸部 I のセッショ ンで5題の発表があった。

草島氏(札幌医大胸部外科) は，漏斗胸の外科之題 し，400例以上の経験を胸骨翻転術後10年以上経過した 症例の遠隔成績と翻転胸骨の態度を胸骨撮影，胸骨シン チグラムにより検討し報告したが，岡，大・田中氏より 胸骨像の認められなかった症例の頻度, 原因, 臨床像な どについて質疑があり，40例中 3 例に胸骨像が認められ なかったか，胸骨の存在は確認されており，その原因は 不明との応答があり，さらに成績向上のための術式の改 良がなされている。

田中氏 (岡山大第 2 外科) は，教室で経験した37例の 胸腺摘除術症例を詳細に検討し, 胸腺腫合併例 (14例) は非合併例に比して術後 2 力月までの近接効果には差は ないが，3年を経過した遠隔効果では成績不良であると 報告した。

大阪市大・白羽氏より，胸腺腫合併例の遠隔効果不良 の原因について質疑があり，胚中心形成度の差異がその 成績に相違をきたす一因となる可能性を指摘した。

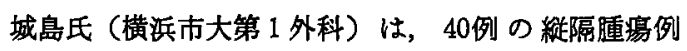
中, 胸腺由来のむのは14例であり,このうち重症筋無力 症は 4 例で，胸腺摘出により改善したもの，増悪したる の，また㭪後肺合併症で失った例について報告し，岡山 大田中氏より術後呼吸管理の方針についての質疑があ ク，気管内挿管などの物理的手段を優先させるとの応答 があった。

庭瀬氏(札幌医大胸部外科) は, 101 例の絽隔腫汮の らち悪性例 8 例の迋隔予後拈よび診断, 治療上興味ある 4 例について報告し, 診断, 治療にあたっての慎重な熊 度の必要性を強調した。

太田氏（東邦大第 1 外科）は, 外科治療を行った自然 気胸症例28例について, その手術適応と治療方針, 手術 方法として腋窩切開を原則としていると報告，これに対 し広島大・西龟氏より, 部位不明, $\mathrm{S}^{6}$, 肺底部に病変あ
るものは腋窝切開ではなく標隼開胸の方が有利であり， また巨大の5胞でる肺胞性のばあいは肺葉切除の必要性 がないとの発言があり，札幌医大・庭瀬氏は血胸例中， 出血点の判明した例について質疑があり, 空着侱離が原 因と考えられる胸壁側からの動脈性出血が認められたと 応答, 座長より, 安静, 穿刺, ドレーン插入による治療 と再発率との関係沉ついて質問があり，今回は検討して いないとの返答があった.

以上,このセッションでの発表演題を総括すれ代，漏 斗胸は整形外科との境界領域であったためにその外科治 療も1，2の限られた施設でのみ行われていたが，最近 は各施設でしかる和田寿郎教授考案に上る胸骨翻転衍が 行われるようになってきている.

緹隔腫湯のなかでる 重症筋無力症に 対する外科治療 は, 免疫学的な要素むあり, 胸腺摘出により効果のある わの，またかえって増悪するなど術後管理をふくめて治 療困難な疾患であり，今後の解明がまたれる分野でああ るが，可及的早期の胸腺摘出と前縰谝周用脂肪組織の倣 清により外科治療の効果も期待される.

また，自然気胸は大気污染之関連してし近年増加の㑯 向にあり，保存療法のみで再発をくりかえす症例は，手 術適応となり, 主としてブラの絴縮むしくは切除術が行 われている。また比較的若年者に多く, 両側性や血胸合 併例もあり，25\%以上の肺虚脱例ではドレーン拽入によ ろ治療法が安静・脱気のみによるもの上りその再発率か; 少ないことから, 初療として積極的にドレーン挿入，液 面下排気法を行うべき疾患である。

胸部 II (IV-6〜11) 座辰 白羽弥右衙門

\section{IV-6. 見逃されそうな肺塞栓症 3 例の検討} 合數中央病院外科

$\begin{array}{rrr}\text { 上原 } & \text { 鳴夫, 平井 潔 } \\ \text { 塩田 } & \text { 昌明, 藤岡 十郎 } \\ \text { 松江赤十字病䟚外科 } & \text { 木村 正也 }\end{array}$

10 月の間に 3 例の肺寨拴症を経験 し, 発症の経過, 胸部レ線に不相応な低酸素血症の存在, 血中 FDP 値の 上昇などから本症を疑い，肺シンチで確定診断を得た。 症例（1）は，乳房切断術後 4 日目にトイレから帰る途中 失神し、ショック症状を伴ったが，酸素投与により血 压, 症状とむに早期に回復した．胸部レ線正常にも拘ら ず, $\mathrm{PO}_{2} 55, \mathrm{PcO}_{2} 28.7$, と低酸素血症が著明なため肺 シンチを行い，右中葉に血流欠損を認めた。ヘパリン, ウロキナーゼ, デキストランによる抗凝固療法で改善し た. 症例 (2)は, 胆のう癌の肝転移のため肝動静脈造影 
を施行し，翌日トイレで失神，チアノーゼが著明であっ たが，酸素投与と㡏夜により改善した。胸部レ線上肺実 質化巽常は認めないが， $\mathrm{Po}_{2} 58.4, \mathrm{Pco}_{2} 31.4$ と低下して いたため肺ンンチ施行，左下葉に血流欠損を認めた。 1 遇間後に右中葉の付加的塞栓を認めたが抗凝固療法によ り改善した。症例 (3)は, 胸内苦閂と呼吸困難で発症, 血王低下，チアノーゼ，冷感があったが，酸素投与，対 症療法で改善. 胸部レ線異常なく血液ガスは $\mathrm{O}_{2}$ マス ク下で, $\mathrm{PO}_{2} 58, \mathrm{Pco}_{2} 29.6$ と低值を示した. A.O.S.C. の診断で開腹, 胆摘, ドレナージを行ったが術後 $\mathrm{Po}_{2}$ が改善せず肺シンチ施行, 右上葉等に血液欠損を認めた ため抗凝固療法を開始したところ順調に改善した。

一上記 3 例的いずれも，発症時腹痛を訴え，また肺梗塞 の合併はなかった．血清酵素值は特異な变化を示さず， FDP は，症例 (1) (40以上) 症例 (2) $(10 \sim 40)$ とも 上昇していた，心電図は心筋梗塞との鑑別に 有用だっ た.

肺塞栓症は增加傾向にあるが，診断に至るためには， ありうべきすのとして本症を積極的に疑ってみることが まず重要と思われた。

IV-7. 㬹脈血栓症からみた肺塞拴症 大阪市立大学第 2 外科

臼井 典彦, 山本 春生, 大野 耕一 月岡一馬, 市川久次郎, 山田 正 酒井 克治

同第 1 内科 田中忠治郎

厚生会高津病院外科

柿木 英佑，上道 哲

下肢静脈血拴症, 自験193例中 4 例伂肺塞栓症の合併 をみた。これら 4 例の下肢静脈血栓の原因は続発性 2 例，特発性 2 例で，血栓閉塞範囲は左㮏减静脈，右大腿 ～滕窝静脈，右大腿静脈，右外腸骨～㮏窩静脈の各 1 例 であり，総腸骨静脈閉塞例はなかった。1例に下大静脈 結禁街を要し，1 例は塊状肺塞栓にて失った。

肺塞栓症の原因としては下肢静脈血栓症が大多数を占 め, Ochsner らは肺塞栓症を下肢静脈血栓症の54\%に, Cabral らは50\%に経験しているが，本邦の山本らは 4 \%に, 自験です $2 \%$ 経験したにすぎない. 肺塞栓症続 発頻度のこの低さこそ本邦下肢静脈血栓症の特徵であ ク,これは左発症の特発性例が多いことに起因するもの と考えられた。

そこで, 本邦人剖検屍の総腸骨動・静脈交叉部の静脈 内膜を娭索すると $50 \%$ 例に異常がみられ，しかむ14\%例
には一部器質化した血栓がみられた。これは欧米例と比 較して非常に高率である。この静脈内膜変化に続発した 血栓か，下行性汇二次血栓を生し，左発症特発性下肢静 脈血栓症を惹起するすのと克えられた。このような例の 中权側血栓はすでに器質化し，静脈壁と癒着しているの で肺塞栓症を続発させる栓子とは成り難い。

一方, 右下肢静脈血栓症では臨床定状を呈しなくてる 上行性の血栓進展を示すことが多いので, 容易に中枢側 血栓を遊離し，肺塞拴症を続発する可能性を示咬した．

\section{IV-8. 反得する喀血一その特殊疾患としての気管支 結石症一} 国立刀根山病院外科

$$
\begin{aligned}
& \text { 中島 篤巳, 桑原 修 } \\
& \text { 田中 英之, 越山健二郎 }
\end{aligned}
$$

気管支結石症の 3 例を報告し, 䠛床的, 病理学的娭討を 加えた. 大喀血は悪性腫湯には比較的少なく，大半が良 性疾患であり，そのほとんどが気管支拡張症として処理 されているのが実状である。しかし喀血量の多い時は気 管支結石症も一応疑ってみる価値はある. 主な症状は， 頑固な咳，血痰，反復性の喀血等があげられる．結石は 第而次気管支までに多く，胸部単純レ線や断層写真，気 管支鏡所見等の詳細な検討が必要である.特に断層像で 気管支壁内や結石の証明が可能なことが多く，外来で診 断出来るものである.

病因論的には次の 3 点があげられる。

(1) 管外性：石灰化リンパ節の管内への移動（肺結 核, Histoplasmosis, coccidiomycosis, silicosis)

(2) 壁内性：気管支軟骨の化骨（加踰）

(3) 管内性：拡張気管支内分泌物の石灰化.

本邦では(1)の結核性のむのが王倒的に多く, 肺内部附 近のリンハ節の石灰化が多い場合は注意を要す，病因解 明のためには，結石の分析よりむ脱灰組織所見の方が有 効であった。

反復する大喀血例の $85 \%$ は死亡すると言われており， 本疾患は手術の絶対的適応と考えられるので，患者救命 のためにも本病名の再認識と早期診断が望まれるところ である.

\section{IV-9. 肺密手術症例の検討} 厷島大学第 2 外科

○西亀 正之, 藤井 俊宏, 土肥 雪彦 児玉 求，江崎 治夫

当科て経験した本年 7 月迄の原発性肺癌症例は 125 例 で切除率は $72 \%$ であった。全症例の 実測 5 年生存率 は 
$33 \%$ で根治術症例は $62 \%$ ，準治空手術症例 $18 \%$ ，姑息手 術や試験開胸例に 5 年生存はない. Surgical TMN 分類 による 5 年率は I 期 $55 \%$ ，II 期 $47 \%$ ，期 $5 \%$ であっ た。期に括ける著しい低下は綎隔リンパ節転移によ るn-factor の影響が強い，肺全摘術は41歳より68葴に わたる17例に施行した。手術死はないが 3 カ月以内の早 期死亡を 5 例経験し心肺機能不全 2 例，肺炎 2 例，対側 肺気胸 1 例等であった．術前肺血流比側定を施行してい るが，患側肺血流が35\%以上の症例に早期死亡例が多 い.しかし全摘による根治性を得た症例は，5年生存 1 例， 4 年生存 4 例と予後は 良い，高龄者肺癌（70歳以 上）の手術症例は10例でいずれる肺葉切除例で最高龄76 歳であった，高龄からくる術前合併症としては肺疾患既 往等呼吸器系, 高血压等の循環器合併症が多く術後経過 に大きく影響する。

早期死亡を 2 例経験した，1 例は激症肝资，1 例は肺炎 にて死亡した，術前管理，術後管理の重要さは当然なが ら術前りスクを考光, limited operation る考虑すべき と思われる。早期診断，適格な手術法と適応の重要さは 当然であるが，術後生存率に及仿す因子として早期死亡 の含める比率は大である.われわれの症例に手術死はな いが早期死亡を 12 例経験した．姑息手術 ( 3 例),試験開 胸（1 例）を除いた症例では，輸血後肝炎 3 例，反対側 気胸を思わす肺虚脱 2 例，カニューV挿入による出血 1 例，気管瘦より胸水呼入窒息 1 例，肺炎 I 例である，以 上の5ち, 肺全摘例か 5 例あり適応の決定に問題を残し た. 又，輸血による術後肝炎の予防と処置に注意すべき である，以上われわれの症例に晾ける術後生存率に影響 する事項, 肺全摘例, 高龄者肺癌, 早期死亡例につき検 討し報告した。

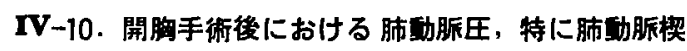
状圧測定の臨床的意

東邦大学第 1 外科

佐々木 忠, 柳沢 正弘 加藤 治, 亀谷 寿彦

近年開胸術が進歩し，高路者，低肺機能患者でも開胸 術が盛んに行なわれるよらになってきている，我々は特 に高龄者, 低肺機能患者もしくは長時間開胸を要する患 者に対して術前より，スワンガンッカテーテルを肺動脈 内に留置固定し，㭪後経時的に肺動脈圧，中心静脈圧， 肺動脈揳入圧，心拍出量を肺外科領域の約60例について 湘定分析してみた. 各々肺動脈平均圧，体血圧，中心静 脈圧，肺動脈揳入匤，心指数を経時的グラフをるって表
現してみた。

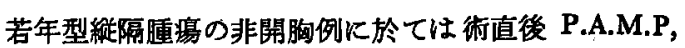
C. V.P. は上年するるのの10時間位迄には正常範囲に回 復してくる．高龄者, あるいは肺切除量が増量すること よにり P.A.M.P. の回復力が遲れると共に肺動脈楔入 压も多少なりとも変動を示し，手術侵襲が增大すると共 にその変動が大きくなってくる，術後出血による再手術 を要する患者, 合併症を起すよらな患者の心肺内压の測 定によって充分に予防が出来る.

我々の施設では肺動脈平均王 $20 \mathrm{mmHg}$ ；中心静脈圧 $10 \mathrm{cmH}_{2} \mathrm{O}$ 肺動脈梛入王 $10 \mathrm{mmHg}$ 以上にならないよ5 に注意している.

結語：1.左心機能は非常に代償能力がすぐれ，すぐに は反応を示さないが，肺動脈揳入圧 (P.A.W.P.)を測 定することにより小さな左心機能の変化を予測できる。

2. 肺外科領域の高龆者に於ては術前評価通り，あ り左心系には負担はかからない。

3. 一端左心采に負荷がかかると回復力が弱まってし まう為，左心機能の状態を見なければならない。

IV-11. 胸部外科領域におけるレーザーメスの使用経 医

東海大学第 1 外科

$$
\text { 山崎 史朗, 小川 純一, 正津 晃 }
$$

同形成外科 $\quad$ ナロン・ニムサクン

昭和52年 9 月より昭和53年 8 月までの 1 年間に本院胸 部外科において Sharplan 791型の 炭酸がスレーザーメ スを用いて7 例の患者に手術を施行した，その内訳性， 開胸術 7 例，肺部分切除 2 例，右肺 $S_{1}, S_{2}$ の区域切除 術 1 例であっそ. 開胸術に際して, 皮庙ならびそ胸筋の 切開に打いて毛細血管性の出血に対してはレーザーメス で充分に止血可能であるか，外径 $1 \mathrm{~mm}$ 以上の血管から の出血に対してはレーザーの止血効果は不充分で, 結禁 または電気メスの補助を必要とした。しかし開胸までの 出血量をレーザー使用群と従来の方法で開胸した群に比 較してみると明らかにレーザー使用群で出血量は少就 った. 100.

肺部分切徐にレーザーメスを使用する際には，腸鈿子 で肺葉を大きくはさみ，肺血流を遮断して行った方が出 血も少なく，切離面もきれいであった，区域切除後の牫 存肺の切離面をみると凝固壊死む少なく，肺実質からの 出血, air leak む少なく創面はきわめてきれいであっ た.

今後転移性肺腫瘍，肺生検に淤ける肺部分切除，良性 
肺疾患に対する区域切除術, さらには不完全分葉の処理 等にレーザーメスを積極的に活用し，その安全性，有奻 性について検討を続けたい。

形成外科 (IV-12 14) 座長 前田 華郎

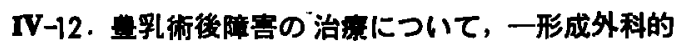
立坦加ら一

東京女子医大形成外科, 吉祥寺整形外科

$\begin{array}{ll} & \text { 上野 冬生 } \\ \text { 杏林大学形成外科 } \quad \text { 大野 宣孝 }\end{array}$

乳房増大術にはシリコンパックプロテーゼをるちいる 方法と, シリュン等の液体を乳房内に注入する, いわゆ る这入法がある. 後者は, 㭪後, 尰瘤形成, 疼痛, 変形 等の後遺症を残すため施行すべきではない，我々は過去 4 年間に23例の注入法による乳房増大術後遺症患者を治 療する経験を得た。

主訴は全例に腫瘤形成を認め, 疼痛19例, 変形8例, 悪珄腫湢を心配するむの3 例である. 主訴に気がつくま での期間は 1 年内 14 例, $1 \sim 2$ 年 5 例， $2 \sim 3$ 年内 5 例 である。

睡瘤は触診ではケイ卵大から乳房全体をしめるむの， 硬度は弾性硬から石様硬まで，周囲に対し移動性のある ものから胸筋内に浸潤し全く移動性の無いものまで様々 である。

微中所見から病型を正型に分類した。

I 型：シリコン液周囲に Fibrosis Tissue $の$ 被膜形成 を認めるもの 5 例.

II 型 : シリコン液の周囲に被膜を認め同時に肉芽腫形 成を認めるるの15例.

III型：液体はびまん性に散在し乳房全体を肉芽腫がし め, 乳腺は識別し得ず, 胸筋内にも強度の漫潤を認める るの 3 例である.

病型と内容物の関係は, シリコンによるもの M I , II 型, パラフィン, ワゼリンによるものは全てII型であっ た.

治療：I－II 型はシリコン液を除去し亦肉芽腫を摘出 しシリコンバッグプロテーゼを挿入した． III 型に対して は乳房内の肉芽腫摘出後, 筋肉は出来るたけ温存しプロ テーゼによる再建を行った。

術後成績，23例中22例が満足している，不満を訴之た 6の1例，再建を施行しなかったため变形をきたした 1 例である. 乳房增大術 (注入後) 障害の治療は単に腫瘤 を摘出したたけでは患者は満足しない，我々は1963 Dr. Thomas cronin によって考案されたクローニンシリコン
ハシッグプロテーゼを術後乳房内, 插入し再建する事によ り良い結果を得ているので報告した。

\section{IV-13. 指尖損伤に対する皮井}

$\begin{array}{ll}\text { 杏林大学形成外科 } & \text { 大野 宣孝 } \\ \text { 吉祥寺整形外科 } & \text { 上野 冬生 }\end{array}$

指尖損侮に対する皮弁は, 以前から，いろいろと工夫 されてきた，我々は，中節骨背側の皮虑を利用した新し い皮弁を工夫した。この皮并は，茎をできるたけ遠位に とり，かつできるたけ，細く，長くして，指尖部に十分 回転できりようにしたるのであり，血行は，遠位から近 位に向 あのにたよっている. 同一指を利用するので, cross-finger flap p thenar flap のような面倒子なく， 又, 一回の手術でよい，又，Kutler kleinert のように 新たに指腹に䑤痕をふやすといらこともない。しかし， 欠点として，皮弁の血行が不安定であり，24例中 7 例 に，完全壊死をきたし，再手術をせざるを得なかった。 又, 知覚といら点です， cross-finger flap と，本質的に は変わらず，特に拇指の場合には，Snow や Hueston の 方法をとるべきと考える。しかし，指を短縮する事な く，最少限の洀痕で，指尖部を，修復又は再建できるの で，拇指以外の，多指にわたる同時損傷の症例には，よ い適応であると考える。

\section{IV-14.微小血管吻合による再建手術} 北海道大学形成外科

$$
\begin{aligned}
& \text { 新富 芳尚, 本田 耕一 } \\
& \text { 飯田 和典, 大浦 武彦 }
\end{aligned}
$$

1975年より微小血管吻合による Free Flap Transferを 用いて再建手術を行って来たので報告した.

再建手術を必要とした原疾患は

悪性腫瘍 4 例 レ線潰瘍 4 例

難治性潰瘍 3 例 顔面片側萎縮症 2 例

洀痕拘樎 2 例 動静脈瘻 1 例

の合計16例であった.

Free Flap の生着結果は

完全生着 12例

部分壊死 3 例

完全壊死 1 例

であった．部分壞死 3 例の内 2 例は脂肪組織が生着し たのでその上に植皮を行ならことで目的を果した。結局 16例中14例に满足すべき結果を得た。

我々が用いた Free Flap は Free Groin Flap, Free D-PFlap, Free Lateral Thoracic Flap の3種であった. 各々について Anatomy を述へ1例ずつ術前術後のスラ 
イドを供覧した。

Free Groin Flap では顔面片側萎縮症

Free D-P Flap では顔面の動静脈瘦

Free Lateral Thoracic Flap では臂部し線潰瘍を供覧し た.

また， recipient site に吻合に適した血管が無かった 乳癌根治手術後のレ線溃㾴について述へたた。方法は大網 を pedicle flap として久損部に移動し，その大網の血 管と Free Groin Flap の血管とを吻合した．結果は満 足すべきるのであった。

微小血管吻合を用いた再手術-Free flap Trausfer は従 来の有茎皮弁に比べ多数の長所を持っていることを述べ た。

\section{座長のまとめ}

前田 䩠郎

豊乳の目的でシリコン液やパラフィンなどの注射が行 われたあとの後遗症として，多数の結節中，睡瘤形成， 乳房の変形，疼痛などについて分類し，これら後遣症の あるものには腫瘤を摘出し，同時にダウコーニン製のシ リコンパッグプロテーゼによる再建を行ったここの度は 22例の症例にこの方法を行い，満足すべき結果を得たと の報告であった.

座長から：シリコンバッグプロテーゼ抙入後，皮下組 織の硬化についての原因と予防法についての質問.

演者から：硬化の原因は術後の fibrosis で予防は術後 の Massage.

座長コメント：数年前まで豊乳の目的でオルガノーゲ ンの注射が巷間で行われていたが，それが硬結や多数の 結節，悪性化，全身症状などの点から，現在ではこの方 法の代りにシリニンパッグプロテーゼが用いられてきて いる.この方法では胸筋と乳腺の間に蒩くので乳腺の隀 瘍を見逃すことるなく，以前のオルガノーゲンの結節を 摘除して同時にシリコンバッグを入れるるのである,

IV-13：指尖部切断創に対しては，従来まで Cross finger-flap p thenar V-Y 法 (kutler, kleinert), bipedicle visor flap (Bunnell), spiral flap(Hueston) volar ad- vancement flap (snow) などがあるが，それぞれ一長一 短がある. 演者の方法は中節骨背側の皮店を円形とし， この皮弁の茎を Midlateral の方へ作成し，この皮并を 起して指尖部へ advance する方法である：この方法を 17人23指に試み， 7 指に壊死，他は比較的良好な結果を 得た，との報告であった。

質疑応答なし.

座長から発言：今後はフラップのデザインに改良を加 えて再び発表の機会を作ってほしい。

座長コメント：指尖部は視力障害者にとっては目の代 りをなす程のものであり，絃楽奏者にとっても指尖は大 切なところである．指尖部の再建法は，できれば有荃皮 并が理想的であり，手術後のまぎらわしさからいえば， 同側指，または同指で行劣ればさらによい，今回はその 点を考虑した方法と思われるが，flap の茎が細すぎた せいか, necrosis になったものも多かった. flap の苼を 幅広くするとか，flap そのものにも改良を加えれば， 将来は良い方法として用いられるようになると思われ る.

IV-4：母床の血行が覀い溃瘍や，遊離植皮では組織 の厚みが補なわれていないような場合, 有茎皮并が用い られるが，近接に恵皮部が選べないような時に，ソケイ 部から血管をつけた皮席，皮下組織をとのままとり，患 部の血管 (動脈と静脈) と顕徽鏡を用いて程合するるの で，演者は顔面片側萎縮やレ線難治性潰瘍など15例に用 いた。

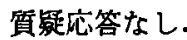

座長コメント：锁小血管吻合術は1960年に始まり1965 年に始めて切断指にこの方法を用いて再接着に成功して いる．現在は骨と血管，筋肉と血管，大網などがこの方 法で遠所に一度で移動可能となった，現在の段階では直 径 $0.5 \mathrm{~mm}$ の血管吻合術が可能である．北海道の医療の 一端として微小血管吻合術が始まったことは同度に耐え ないところであり，災害による指の再接着術が高度の成 功率に行われる日が近いことを深く望んでやまない。

\section{第IV会場 午後の部}

\section{頭部外侮（IV-15～16）宮崎 雄二 \\ IV-15. 重症頭部外侮とCT 像一その経時的変化を 中心として一 \\ 君津中央病院脳神経外科}

小野 純一, 中村 孝雄, 礒部 勝見

\section{千葉大学胘神経外科}

山浦晶, 牧野 博安 急性期重症頭部外侮の診断及び 術後程過を CT スキ ナンにより追跡し，従来の遒血管撮影では的確な診断が 困難とされていた合併血腫, 限局性浮腫, 脳室変形、脳 
挫伤の拡がりなどの頭蓋内変化を程時的に観察し，その 予後との相関について検討した，症例は $2 \sim 74$ 藏までの 重症頭部外侮例36例であり, 性比は 5：1 2 男性に多 い.すべてが天幕上病変で, 硬膜下血尰が 11 例と最る多 〈, ついで 合併血腫 8 例，硬膜外血腫 6 例，脳挫鹪 5 例，脳内血腫 3 例，開放性陥没骨析 1 例の順である. 重 症頭部外鹪例の予後の評価にあたり，年龄，意識状態，

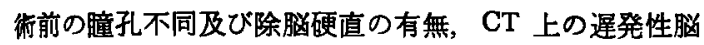
内高吸収域及び後頭葉内低吸収域の有無を検討した。遅 発性脳内高吸収域は挫鹪脳の拡がり，ナなから減圧佈又 はマニトール投与などによる脳圧低下のためめ小静脈か らの Oozing に起因するとされ，また後頭葉内低吸収 城は，天幕へルニアによる後大脳動脈の循賟障害に起因 し，典型的にはクサビ形となると考兄られている．以上 の結果より，遅発性脳内高吸収域及び後頭葉内低吸収域 は街前の 意識状態が悪く，さらには除媨硬直に 至った 例，特に40咸以上に出現頻度が高く，これの出現は予後 不良を意味する．硬膜血腫例恃他の血腫例に比し，遅発 性脳内高吸収域及び 後頭葉内低吸収域の出現頻度が高 い.また脳室内出血例手後不良である．以上重症頭部 外隻例の予後の評価には CT スキャンの経時的観察が 必須である。

\section{IV-16. 外倩性後頭部硬膜外血堙について}

東京女子医大第 2 病院外科

$\begin{array}{lll}\text { 佐藤 } & \text { 範夫, 井上 } & \text { 久司 } \\ \text { 井合 晢, 市川 } & \text { 辰夫 }\end{array}$

湯沢外科病院 湯沢 敏

外賃性後頭部硬膜外血腫は稀な疾患であるが，我々は 過去 3 年間に 6 例経験したのて，臨床症状，脳血管撮影， 手啐等について，考察を加えここに報告する．対象は当 院及び 湯沢外科病院に括ける頭部外傷患者1783名とし た. 手術を行なった外傷性頭蓋内血腫18名のうち後頭部 硬膜外血腫は 6 例である.テント上が 5 例，テント上下 わたるもの1例である。臨床症状では意識障害, 呕吐が に多い，頭部単純X線撮影にて骨析線を認めたもの 4 例，脳血管掫影で 無血管野 5 例， extravasation 3 例， AC shift 2 例，accordion sign 3 例，テント下にわたる 血腫例では kewpid bar の消失, PICA の下方偏位があ った. 主出血点として骨折線より 4 例，中硬膜動脈より 2 例であった。血腫量は20～200g であった。予後は軽 快 5 例，死亡 1 例で，死亡例は搬入がおくれたためであ る. 結論，外傷性後頭部硬膜外血腫の原因は骨折線及び 中硬膜動脈末梢部よりの出血が多い為, 出血が徐々に来
たし症状発現までの時間が長い、テント下まで血腫が及 んた際は小脳症状が出現した，血管撮影で無血管野の確 認は此較的困難である. sylvian triangle の移動は, accordion sign $50 \%$, candeveral sign $17 \%$ ，下方偏位 17 \%であり，血腫の存在をよく反映する，診断全体をみる と比較的困難であるが，神経学的な観察と適切な時期の 検査を行なえば差程でむなく手術にて救命しうる。

\section{座長のまとめ}

宮崎 雄二

脳神経外科関係の演題は頭部外傷に関する 2 題のみで あり,これら 2 題中の 1 題は重症頭部外傷の CT (Computed Tomography) 所見についてであり，他の 1 題は後 頭部硬膜外血腫と題する演題であった。

近年の本邦における CT の普及には世界各国に 類を 見ない瓜どの著るしすががありこのCTの診断価值 は頭部のみならず全身について広く認められてきてい る. 演題IV-15の君津中央病院脳神経外科の小野純一氏 らは CT を実施した30例の重症頭部外傷例について検 討し，脳内血腫が媨室内へ穿破した例 おょび Contre coup 例について詳細に 報告した，小野氏らはまた重症 頭部外傷例 に批る外減圧手術後の CT 像について外 減圧手衍部辺椂に高吸収域が出現することを始めて注目 し，これが骨縁による直接脳圧迫のための点状出血㧍よ び循環障害のための出血性脳硬塞であるとした。また 外減圧衍後に 出現する 遅発性脳内高吸収域について指 摘し，こ礼は脳圧の 急激な下降のための小静脈からの Oozing によるとした．頭部外傷例におけるCT 検查法 の今後の価値は血腫存在の診断にとどまらず，外減王手 術前後の頭蓋内病態の追究更に頭部外傷例における脳の 動態追究にあると考觉る。

近年外傷性頭蓋内血腫例の增加によって従来は発生部 位が非定型的とされていた様な硬瞙血腫に遭遇すること も桸でななくってきている．そのーつつに天幕上頭蓋内後 部に発生する硬膜外血腫扣よび後頭蓋窩硬膜外血腫があ る.これらを一括して外傷性後頭部硬瞙外血腫として東 京女子医大第 2 病院脳神経外科の佐藤範夫氏らが発表し た. 氏らはこれら6例の症候， $\mathbf{X}$ 線検查所見について述 べたが，座長はこれら天幕上後頭部硬膜外血腫と後頭蓄 骷硬獏外血腫は出血源, 症候, 沿療法が異なるため一括 すべきではなく，後方偏在硬膜外血腫，横洞上下型硬膜 外血腫，後頭蓋䈑硬膜外血庫に 3 分して検討されるべき ことを強調した。

$$
\text { 外伤（IV-17〜20）座長 須藤 政产 }
$$

\section{IV-17. 重複外侮の治痖経験とその予後}




\section{八千代病院外科}

佐藤太一郎, 七野 滋彦, 前田 正司
磯部 豊, 岸本 秀雄, 河野 弘
秋田 幸彦

重複外傷は「個々の損傷の相加作用ではなく，個々の 損傷の相乗効果により，個体に重大な影響を与兄るこ と」「現状のように各科各分立の医療機関では此の上5 な症例をどのよらに扱らか」などの問題を含んでいる. 我々は最近 7 年間に外傷入院患者3641例を扱い，その5 ち124例が重複外傷であった。

男99例，女25例，年龄別では20歳代に最も多かった。 重复外傷の定義は太田や加来の基準を用いた. 此症例群 の重症度を小川・杉本の外傷指数で示すと12〜36点で, 平均20.5点であった．また損傷の組合せをPizzi の分類 に当嵌めると，

I. 多発組織損傷 21 例

II · 聑幹骨析, 泌尿器損傷とそのほか 9 例

III.中枢神経系損傷と明白な合併損傷 49例

IV. 中枢神経系損傷と隠九た合併損傷 6 例

V. 呼吸障害にほかの損傷を伴うむの 18例

VI. 腹部内䠞破裂に合併損傷あるもの 21 例

これらのらち緊急手術を要したすのは30例で開頭術 7 例, 開腹術 19 例. 開胸開腹術 2 例, 額骨固定 1 例, 大血 管䉽合 1 例であった。

生存104例は入院期間は 1 カ月以内が 10例， 2 力月以 内が27例，3カ月以内が23例で, 全体の平均は114.9日 であった. 合併症としては脂肪栓塞 1 例, 破傷風 1 例, ガス壊瘨 1 例, B 型肝炎 5 例, 肝炎 2 例，耳下腺炎 1 例 であった. 生存例の外傷指数は平均19.5点であった。

死亡20例の入院期間は 1 日以内が11例，2 日以内が 4 例で, 最長20日，平均3.0日であった。死因として考え られたのは出血 4 例，呼吸障害 2 例，脳損傷 9 例，頭部 外傷と胸部外傷の合併 5 例であった。

最近 7 年間に経験した重複外傷124例を 分析し，次の 結果を得た。

(1) 頭部外傷を含む重复外傷で死亡率が高い.

(2) 外傷指数 $22 \sim 25$ 点で死亡率が高い.

(3) 緊急手術の順序は熟虑すべきである。

\section{IV-18．亘複外㥂一殊に腹部外偒を中心に一}

\section{久留米大学第 1 外科 中村 征規}

教室では昭和 43 年から昭和52年迄の過去 10 年間に外傷 症例112例を経験した．その内訳は腹部外傷55例，胸部 外傷36例，その他21例であった. 今回は特に頭部外傷を
中心に統計的観察を行ない2，3の知見を得た。

腹部外傷の原因としては交通外傷が36例と圧倒的に多 く, 年踰別では20歳台が最も多く40歳迄が70\%を占めて いた．また，腹部外傷55例中，腹部単独提傷は36例，重 複損傷を伴なった症例は19例で，それらの手術率は前者 は36例中29例の $80 \%$ ，後者は19例中16例の84\% であっ た. 次に, 臟器別椇傷部位では小腸が最も多く, 肝, 脾，膵，十二指腸と続き，それらの手術死亡率は，腹部 単独損傷では29例中 4 例の $14 \%$ ，腹部とその他の部位の 重複損傷は16例中 3 例の $18.8 \%$ であり, 腹部外傷全体で は45例中 7 例の $15.6 \%$ あっった。

腹部外傷の死亡原因をまとめてみると，出血性ショッ ク，腹膜炎によるエンドトキシンショック，重篤な重複 外傷, 受傷より手術迄の時間の長さなどであった。最後 に代表 2 症例を拳げた. すなわち

症例 $1: 37$ 歳. 主 交通事故で腹部, 胸部, 両㮏部を 打撲, 貝血, 腹部膨満があり, 腹部レ線像で free air が 認められた。開腹所見では $\mathbf{S}$ 字状結晹断裂, 回腸壊死, 腸間膜断裂などが認められたが，その術後経過は良好で あった。

症例 $2: 19$ 歳, 今, 交通事故で, 胸腹部, 大腿部打撲 で来院, 胸腹部単純レ線像で, 左第11肋骨が認められ, 脾損傷を疑い開腹した．術後経過は良好であった。

これら 2 例から腹部外傷時には胸腹部単純レ線像は不 可欠で，腹部単純 $レ$ 線像で，free air，腹腔内の fluid level 等により消化管の破裂を知り, 胸部単純レ線像で の下部肋骨骨折は肝，脾甈の損傷を寲ってみるべきであ ることを再確認した．以上私共が経験した腹部外傷症例 を統計的に観察し，上記のような 2 例を供覧した。

\section{IV-19. 消化管外侮例の検討}

鶴岡市立荘内病院外科

○鉿木 伸男, 斉藤 博, 石橋 清

昭和39年 1 月から53年 8 月までに当科で経験した腹部 外傷の 手術例は101例（今79，ㅇ22）であり，損傷葴器 別には消化管では小腸が最も多く, 実質荿器では肝蔵, 脾蔵が多かったが，今回はこの中の消化管および腸間膜 の損傷60例について臓器別に検討を加え, 各脸器の損傷 の特徽あるいは問題点を報告する。

胃 (4 例)：原因として刺傷即ち開放性損傷に依るむ のが多かった．また開腹時に胃後壁の損傷を見逃さない ように網荎を開いて精査する必要があり，事実，吾々の 1 例は網慗の中に飯粒，わかめが見えたため同部を開い て胃後壁の損傷を発見した。 
十二指腸 ( 9 例) : 下行部, 下水平部の所謂後腹膜破 裂の場合には, 初めは腹部症状がそしく，診断が困難な ため開腹時期の遅れることが多く，吾々の同部の損傷 4 例中，腹壁損傷を伴った 1 例を除いて他の 3 例は初猃後 10時間以上を経て漸く手術に踏み切った。

小腸（24例）：損傷部位は小腸全長に亘って満遍なく みられ，むた興味あることに小腸の中央部の損傷 6 例に は2 ケ所以上の複数損傷がみられた. またX線写真にお ける横隔膜下ガス像は受傷後早期には梕められず, 受傷 3時間後に漸く出現した。なお小腸ガス像あるいは二ボ 一の存在も有力な診断根拠となる.

結腸（8 例）：正中線で外力と资椎骨との間に㣣まれ て損傷されるためか部位的には横行結腸の中央部か $\mathrm{S}$ 状 結腸にみられ，また結腸が損傷を受けるためには相当に 強い外力が必要なためか，結腸のみの単独損傷は少な く，重複外傷の形をとるるのが多かった。

直腸（1 例）：9歳の男子が木から転落して尻餅をつ いた漈、木のくいが肛門内に突き刺さり，更に腹膜翻転 部の高さで直腸前壁を゙貫通した所謂杙創の稀な症例であ った.

腸間膜（14例）：出血量が非常に多く，そのためショ ックに陥り易く，また腸間膜の血管損傷に伴って腸管の 血行障害をきたした症例が多かった。

IV-20. 鈍的外像による十二指腸後腹膜破致の 4 例 日本医科大学救命救急せンター

$\begin{array}{lrl}\text { 柳 } & \text { 郁夫, 山本 } & \text { 保博 } \\ \text { 辺見 } & \text { 弘, 大塚 } & \text { 敏文 }\end{array}$

当センターにおいて経験した十二指腸後腹膜破裂 4 症 例の概要について述べた。

過去 3 年間に経験した腹部外傷116例の内，鈍的外傷 による十二指腸損傷は 6 例, 内, 後腹膜破裂は 4 例（鈍 的外傷の $4.9 \%$ ).

性別は全例男性, 年龄は27〜39歳, 受倡原因はハンド

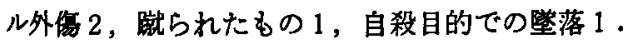

レントゲン所見上， 3 例は後腹膜ガス像なく 1 例で受 傷 8 時間後, 少量の後腹膜ガス像を認めた。ガストログ ラフインによる消化管造影では施行した 2 例とも漏洩は 認めない.

腹腔穿刺で 3 例に血性液の排出を認めたため腹腔内出

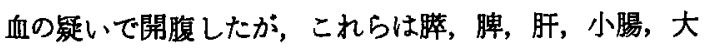
腸，腸間膜等の合併損偤があり，この合併損復が開腹決 定の主因をなしていた．腹腔穿刺陰性の1 例は腸管破裂 の战いで開腹した、したがって術前，本症を的確に診断
したものはない.

術式については，我々は損傷部の修復と共に減王が最 重要と考えており， 1 例で膵頭部挫減を伴っていたため 脺頭頭十二指腸切除， 2 例に空置的胃切除，Row $x-Y$ 吻 合，外十二指腸瘦造設を，他の 1 例は硬膜外血腫除去例 と同時手術であり全身状態不良のため空腸パッチ法，外 十二指腸瘦造設, 空腸栄差㾇造設を施行した.

予後は 2 例で急性腎不全や外傷性脺共で死亡したが， 直接，本症に起因する死因，合併症は経験しなかった。

以上，我々の経験した症例を報告したが，診断は困難 なことが多いため，腹部外傷，特にハンドル外傷例では 本症を常に念頭におき，注意深い経時的な観察の重要性 を強調した。

\section{幽長のまとめ 須蔳 政彦}

IV-17は八千代病院佐藤氏らによる重複外傷の統計で あり, Pizzi の分類によって考察したものであるが, 重 複外傷の分析は現在でるなかなか困難な点が多い，重 複外傷を取扱うときの大きな問題点として triage があ り，その正否が予後を左右することすらある. 座長の質 問に対し演者はすべて訓練された外科医が triage して いると答えられたが，現状では合理的な方法といえよ 5 .

IV-18は久留米大中村氏らによる腹部外傷を中心とし た重複外傷例の統計に関する発表である.腹部外傷は 1 例ごとに実態が異なり，また 1 施設ごとに統計の内容が 若千異なっている.たとえば堅損傷は腹部外傷中頻発す る損傷であるが演者らの統計でそれが少ないのは別に泌 尿器科がそれを取扱っているためであろらか，八千代病 院佐藤氏から，脾損傷でデファンスが出現することは少 ないと思うがどの位の率で出現したかとの質問があり， 演者すデファンスのあるむのは少なかったとの答であっ た. 実質葴器損傷では消化管破裂に較べ，デファンスの 程度の軽いむのが多いが，しかし殆んどの例で多少のデ ファンスはみられるものであり，時に消化管破裂を思わ しめる程デファンスの強い症例すある.kehr症状は重 視される程は出現率の高いすのではない，

IV-19は鶴岡市立荘内病院鉿木氏らによる消化管外傷 例の検討である. 小腸損傷が小腸全域にみられたこと, 結腸では横行結腸中央やS 状結腸中央に損傷がみられた ことなどから，消化管鈍的外傷の発生機序を直達外力に よるすのと考察された点は同感である．しかし少数では あるが inertial power によると思われる 直腸腹膜釉転 部の損傷をみることすあり，その点についての座長の質 
問に対し，演者はそのような症例はなかったと答えられ た。また十二指腸後腹膜破裂の初期症状に関する座長の 質問に対し，演者は何らの局所々見も見られなかったの ではなく，開腹に踏み切る程の著明な腹部所見はなかっ たといら意味であると答えられた。本損傷の早期診断に は本損傷の存在を念頭に置いて㛶細な症状所見を捉えて 十二指腸造影などを行い診断するのがよいであるう．腸 問膜破裂で腸管の血行障害を伴ら例が多かったとの発表 に対し，八千代病院佐藤氏は血管走行に沿与破裂が多い のでこのようなものでは腸㨽死の危険は少ないと述へ， 座長すとれと同じ見解を述へた。

IV一20は日本医大柳氏らによる十二指腸の鈍的後腹膜 破裂 4 例の報告である. 座長らは本損傷の診断にガスト ログラフィンによる十二指腸造影が有用であると考えて いるので, 報告された十二指腸造影陰性例について, 䧔 性であったことを納得せしめる手術所見であったか否か を質問したが，手術所見からは当然陽性であってもよい と考えられたとの答であった. 遠隔操作ではなく直接手 で压迫を加えたり，体位を工夫してみる必要があろらと 考えられる.十二指腸後腹膜破裂の手術には十二指腸内 圧の減压が重要であり，演者らが 4 例とも単純 2 層縫合 を行わず他の術式を採用したことはまことに賢明な術式 選択であったとい光よ5。荘内病院鈴木氏も単純释合， 胃チュープによる減压での苦い経験から，十二指晹内圧 の十分な減压が重要であると強調された。

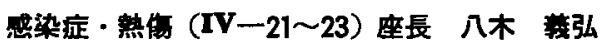

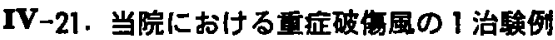
川崎市立川猗病院外科

水渡 哲史，横山 茂樹，前原 正明

横山 勲，東條 慧，新井 健之

滝沢 秀浩, 山田 良成, 斉藤 敏明

当院において重症破傷風の一治験例を経験したので報 告する。症例は，11葴の生生来健康な男児で，6日前， 運動場にて右下腿部を受傷し，開口障害をきたして来院 した. ただちにデブリードマン及び，抗毒素血清を注射 したか，開口障害より約24時間後に全身痤挛が出現した ため，気管切開施行し調節呼吸を行なった．経過中，何 回かペンチレーターよりの離脱を試みるる，その都度敨 しい痤挛のため失敗している。また血圧，脈迫の変動は 激しく、そのコントロールには困難を要した。

栄羡面に虰いては，経口摄取可能となるまで，経中心 静脈高カロリー輸液を行なった。

調節呼吸18日間施行後ようゃく疼挛もおさより，抗痤
挛剂を減量し，自発呼吸に切换え20日目には完全にベン チレーターよりの離脱に成功した．筋肉機能回復訓練の 後，機能障害を残さず元気に退院した。

使用薬剂は, TIG 8750U (総量) Pc-G 2 億2000万U (総量), diazepam 240 480mg/day Pancronium 96 $144 \mathrm{mg} /$ day, chlorpromazin $150 \sim 200 \mathrm{mg} /$ day であり, 他 に強心剂，抗生刻む併用した．極期には，30分每に diazepam 10mg, Pancronium 2〜3mg を静注し、コントロ 一ルしえた。当症例は全身状態の改善後尖足が残り，そ の回復に 2 カ月を要したが，重症と考光られる症例に は，ギブス固定等の予防的処置が望ましいと思われる。 なお当症例は，三種混合ワクチン接種をらけておらず, 受䅞時，および退院時にトキソイドを注射した。

以上重症破傷風の一治験例を経験したので報告した。

IV-22. 当科におけるガス壤瘟症例の検討 大阪大学特殊救急部

$$
\begin{aligned}
& \text { 杉本 寿, 小林 久, 高橋 道知 } \\
& \text { 寒川 昌明, 吉岡 敏治, 杉本 㫛 }
\end{aligned}
$$

当科では過去11年間に22例のガス壊痘应例を経験した ので，その概要を報告した。

症例の内訳は，男性19例，女性 3 例，年龄は10〜 48 藏，平均32歳，成人男子に多く認められた。腹部術創に 感染した 1 症例を除く 21 症例に外傷歷があり，受侮して 4 時間から13日，平均 3 日後に発症している.

細菌学的検索では Clostridium 属11例 (らち Cl - perfringens 7 例)を認めた他, anaerobic Strept., Enterobacter., Klebsiella. Strept. faecalis. Staphy. edidermis 等が検出されている.

当科では来院後直ちに，創の開放，最小限度のデブリ ードマン，高圧酸素療法，PC-G を中心とする抗生物質 大量療法を行なっているが，生命に対する予後は良く， 死亡例は破傷風を合併し呼吸管理中に敗血症で失った 1 例と，来院時すでに沉発性腹膜资による敗血症に陥って いた 1 例の計 2 例に過ぎない，他方，生存例20例中， 9 例に患肢切断がなされており，患肢に関する予後は不满 足な状態である。ところで，ガス壊瘟の進行度を X-P ガス像より, Grade I ：浮腫像を主とするすの, Grade II：皮下の散在性ガス像, Grade III : 皮下及び筋層に治 った帯状のガス像，Grade IV : 筇層内のチリソン状のガ 不像の 4 段階に分類し，症例を検討したところ，来院時 Grade III での症例は全例患肢切断は不要であったが， Grade IVの症例は 6 例中 5 例 までが最䅂的に壊死部が demarcate してから患肢を切断されている. 残りの患肢 
切断例 4 例は他院で切断されてから来院した症例と、循 璪再開通に失敗した接着肢である。

ガス壊瘨は創傷の初期治療の基本に忠実であることに よって予防すべき疾患であるが，不幸にして発生した場 合には，発热，疼痛，局所所見の経時的観察を急らず， 幄くとも，Grade III むでの時期に発見し，高仼酸素療法 が可能な施設に急送することが，患肢予後とを改善しう る唯一の方法であると考兄られる。

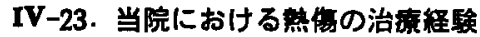

\section{平家市民病院外科}

青木 明人, 中山 隆市, 岡芹 繁夫

木村 嘉憲, 別所 隆, 浅越 辰男

中田 宗彦, 田村 謙二

昭和45年上り昭和53年 9 月迄の 8 年間当院外科におい て入院治療を行った熱傷症例は75例で，同期間入院数の 約 $2 \%$ ある.

年齢別頻度では 5 歳迄と 10 歳 30 歳の年齢層に多発 L, 受傷範围別では30\%以下が約 3 分の 2 症例を占めて 多小.

受傷機序で忙食品等の過熱液体にふれた例，ブロパン ガス爆発等が多く，熱傷深度との関係では，熱湯風呂， ガスバックファイャーでは 2 度か，過熱液体，火焰，電 気スペークの労働災害は 3 度となる症例が多く，受䅞機 点の検討は治療方針の決定に重要である。

全身療法は，受傷面積の 算定，尿量，血圧の一般状 態，検查所見等により補液量を調節しているが， pH.， $\mathrm{PaO}_{2}$, B.E. 等の血液ガスを受傷直後の24時間は頻回に 测定し，この値の修正も積極的に行って, 呼吸障害の発 生予知や，その対策に利用している.

受鹪籁囲と入院期間は，40\%以上は 1 カ月以上である のK対 L $30 \%$ 以下は要植皮例を除 1 カ月以内に退院し ている.

局所療法は，0.5\%硝酸銀溶液を使用しているが，， ーパードタンクの使用も積極的に併用し，創の清浄化を はかっている。

硝酸銀療法にともなら電解質異常については特に認め なかった.

死亡症例情歳以上の老人 2 例と 3 歳以下の幼坚 4 例 であり，老人例の 1 例は自宅治療による破傷風併発例で あり，この予防処置の重要性を示するのである． 3 歳以 下の症例は 1 例のショック死を除き, 受傷後 $3 \sim 8$ 日目 に呼吸障害を起こして死亡した。剖検病理組織標本にて 肺水腫様変化を示した。
以上われわれの熱傷例を検討し，全身療法については 血液ガス所見等も参考に利用し，上り適切な初期治療の 必要性について述べた。

\section{座長のまとめ}

\section{八木 蕒弘}

この section は感染症としての破傷風，ガス壤疸，そ れに熱傷の発表であった.

まず川崎病院より重症破傷風の一治験例について，報 告があった。この症例は開口障害から24時間後に全身疼 率が出現し，気管切開を行ったのち鎮静剤，抗疼挛郕， 筋弛緩㘊などを用い、調節呼吸を行いながら救命し得たる のであった．破傷風の発生頻度は近年減少して来てはい るすのの重症の場合の死亡率は高く，発症後の抗毒素血 清の効果も充分でないため，その治療は非常に困難なる のである. 中でる㽻窂発作のための呼吸困難に対する管 理はむずかしく respirator をはずす目安などについて今 後の発表が期待される.

次に大阪大学上りガス壊㾴についての報告が行われ た。ガス壊瘨は男子にその発症が多く，全例に外傷歴が あり，受傷後 4 時間から13日後に 発症をみるようであ る.原因菌としては clostridium 㬝が多いということで あった。

従来よりガス壊瘨は四肢の切断，重症例での死亡など という治療が困難なるのの1つであったが，高圧酸素療 法と PC-G の大量投与によりその治療成績が非常によ くなったことかが報告された：また四肢の切断もこの治 療法によりさけ得る症例が多くなったといら報告は今後 のガス壊誼患者にとって大きな支えになるであろう．

最後に平塚市民病院から72例の熱傷患者の治療につい ての 報告があった．72例中死亡は 6 例で死亡率は8.3\% であったが, 死亡例は 2 歳前後と70歳前後に集中してお り，種々の報告にみられるように幼小児，老人の救命の むずかしさを物語っているようである．な扰死亡例中の 呼吸不全例については輸液過剩汇上る肺水腫む考えられ ないかとの質問に対して最近の症例でないのでその可能 性むあるとの解答があり，輸液のむずかしさの一面を表 わしていたようである。

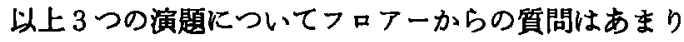
なかったが，いずれる臨床治療上，非常に意義のある発 表であり，今後の治療に大いに役立つるのであると考え ている。

麻醉（IV-24 29）克長 古川 幸道

IV-24. 経口投与による前投藤の評価

東京慈恵会医科大学麻醉科 
○根津 武彦，森永 誠子，倉田隆 田村 次郎, 谷藤 泰正, 小林 建一

释ロアトロピンにトランキライザーを併用し，経口投 与による前投薬の評価を，慣習的な筋注による前投薬と 比較しながら，臨床的におこなった。

筋注鎮静剤として Pentobarbital $2.0 \mathrm{mg} / \mathrm{kg}$ Hydroxyzine $2.0 \mathrm{mg} / \mathrm{kg}$ を用い，アト䓃ピンの筋注 $(0.5 \mathrm{mg})$, 䋊 ロ (1.0mg群および1.5mg) により 3 群に分類し、アト ロピンの至適量を求めた. 同時にトランキライザーの二 トラゼハムをを経口投与し経ロアトロピン $1.0 \mathrm{mg}$ と 1.5 mg により，2 群に分類し比較した。

5 群とも各群間で脈拍, 血圧の変化の程度に差は認め られず，又前投薬投与前後の変化にす差がなく，循環系 にはほとんど影箤がない，又小児にアトロピン0.04mg/ $\mathrm{kg}$ とトランキライザーを経口投与した群でも循環系に 対する影響は認められない。

分泌抑制の面では，アトロピン1.0m と鎮静剤を筋 注した群を除いて各群ともてトロピン0.5mg 筇注群と 変化なく、ニトラゼパムとの組み合せではアトロピンの 経口投与量は1.0mgでよいことがわかり，又小児では $0.04 \mathrm{mg} / \mathrm{kg}$ で充分との結論を得た.

鎮静剂の呼吸中权へ対する作用を $\mathrm{CO}_{2}$-response curve により評価した．5，10，15mg のニトラゼパムを成人 に投与しても呼吸中枢に対する影響は認められなかっ た.しかし5mg のニトラゼパムを老人症例に投与した ところ，呼吸抑制を示す症例があり，使用にあたって留 意する必要があると言える。

フトロピンを経口投与して，口妧内分泌量の变化を30 分ごと120分まで調べたところ，90分值120分值は control 值に比して有意に低下を示した．しかし症例によ り，低下を認めない症例もあった。

以上の検索よりアトロピン1.0mg とトランキライザ 一の導入前90分の経口投与は，筋注前投薬によるとほほ 同じ効果を期待しらるとの結論を得た。

IV-25. 笑気・酸素既湦合ガスの臨床応用について 札幌医科大学麻酔科

○高橋 長雄, 並木 昭義 大町 英世, 角田 一真

1. 笑気は鎮痛作用の顕著な割に催眠作用が弱いた め，単独で使用する麻醉薬としては過小価される傾向に ある．われわれは85例の外来の小手術（子宮内容除去 術）に笑気 $50 \%$ ，酸素 $50 \%$ の既混合ガスを用いて麻酔を 行い，評価として Dundee I〜I a (满足すべき麻酔〜
手術操作の阻け゚とならない程度の良好な麻䣲）が全例の 95\%を占めた. 麻酔の導入は深呼吸を15回, 時間にして 1 分30秒で，忹完了でき，麻酔終了後は10秒で見当 識回復, 40分後起立可能となった. 麻酔開始20分前に diazepam 5 10mg 静注をつけ加えることによりDundee 評価はさらに改善されるが，起立可能になった際，わず かに酩酸感が残るものが出てくる.

2. 胆焉摘出 手術 12 例, 胃切除 7 例, 食道離断術 2 例，泽腹椎体削開術 1 例をらけた男性10例，女性12例の 計 22 例の上腹部手術後の術後呼吸管理に笑気 $30 \% \cdot$ 酸素 70\%の混合ガスを用いIPPBで吸入させた。ベネット PR2 を用い術後15時間（平均）後上り 1 日朝夕 2 回吸入 させ10〜20回の吸入後意識的に咳濑，喀痰の排出をさせ るといら方式で 1 回約10分間続けた，吸入終了後平均 85 分間鎮痛が続き，深呼吸を自由に行えたばかりでなく， 術後の鎮痛剂注射量が半減した.

3. 笑気 $50 \%$ ・酸素 $50 \%$ 既混合ガスの深呼吸による吸 入と，50\%窒素・50\%酸素および空気吸入時との間で一 回拍出量, 心拍出量, 血圧, 総末梢血管抵抗, 血液ガス の諸値について比較を行った. 対象は男38例，女34例の 72例. 深呼吸50回繰返したあとで，65歳以下の患者では 一回拍出量, 心拍出量とも火增加, 総末梢血管抵抗の低 下がみられた．65歳以上では全く対踇的变化をみた。 65歳以下の成人では末梢血管の抎張と，それに対応する 心機能の亢進がみられたのに対し，65歳以上では麻酔状 態に陷って心機能の 軽度の 抑制が起るものと考えられ た.これらの変化は坚素あるいは空気吸入時とす相異し た.

\section{IV-26. 整形外科手術に対する低血圧麻䣷のに用} 旭川医科大学麻酔科

藤原 慎司, 劍物 焂, 桜谷 香織
岩野
小川英明, 水柿 功, 菅野 吉一
小秀道

同 整形外科 安藤 御史, 平山隆三 原田 吉雄, 竹光 義治

術中出血量を減少させて手術操作を容易にする目的で 低血圧麻酔が応用される．今回我々は比較的大量出血が 予想される整形外科手術のハーリントン手術, 股関節全 置換術と骨切り術, 椎弓切除術の 3 群に本法を応用し, 出血量, 手術時間, 術後肝, 腎機能の変化を, それぞれ 正常血圧群（以後 N-group）と比較した。一部の症例で は低血圧時の lactate pyruvats 值の変動を調べた。対象 とした患者は, ASA 分類による Risk I ないしIIのもの 
とした。低血圧群（以後 H-group）は，ハーリントン手 街 4 例, 椎弓切除術 8 例, 股関節全置換術群 4 例の計 16 例，N-group は，それぞれ 4 例，8例，17例の計29例で ある。前投薬には， hydroxyzine $100 \mathrm{mg}$, atropine 0.5 mg を用い，麻酔は GOF あるいは，NLA 原法で維持 $\iota$, trimethaphan の持続点滴にて, 術中収縮期血圧を80 から90mmHg に維持した。 メーリントン手術に揖いて

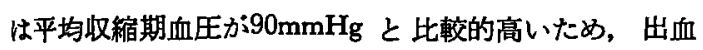
量に有意な差は認めなかったが，81から85 $\mathrm{mmHg}$ 火維 持した椎弓切除術と股関節全置換術群では術中, 全出血 量において，H group が $\mathrm{N}$ group の1/2から1/3の出血量 であった。全体的に術後出血量を手術時間には有意差は みとめられなかった。 trimethaphan 使用量は, GOF 麻 醉比比し, NLA 原法では, その使用量が 2 から 4 倍を 增加した. 又, 使用量が $10 \mathrm{mg} / \mathrm{kg}$ 越えると trimethaphan の滴下速度を速めても血圧が下降しつらく tachyphylaxis の傾向がみられた．まだ低血圧時の lactate，pyruvate 值はいずれも正常値の範团内にあった. 本法によ る術後の肝, 堅機能障害はみとめられなかったが, メー リントン手術, 椎弓切除術の一部に LPH のみが高值を しめしたものがあるが，これは，低血厌麻酔によるとは 考え難く，広範囲な手術操作㲹起因すると思われる．

IV-27. 颞部および胸部硬膜外麻醉の呼吸への影翌 札幌医科大学麻醉科

○高崎 真弓，矢尾久美子 小坂 義弘, 高橋 長雄

札蜆医科大学麻醉科では総麻醉症例の 4 分の 1 を硬膜 外麻醉 (硬麻) で行っている. 穿刺部位に上る分類で は，最も多いのが腰部硬麻（57\%)であるが，胸部硬麻 (21\%)や仙骨麻 (15\%) 女利用している.さらに最 近ては，乳腺や上肢の手術に頝部硬麻 $(7 \%)$ を利用し ている.

硬麻は末梢性の知覚神経麻癣を起こすことによって無 通を得るるのであるから, 頝部や胸部で行らと, 同時に 呼吸に関する運動神経の麻疩む加わる.これら硬麻によ る呼吸抑制の程度を検討した。

硬麻は患側を下にした側卧位で穿刺し，2\% mepivacaine $10 \mathrm{ml}$ を Tuohy 針より20秒で注入し，25分後に動 脈血ガス分析を，30分後よりスパイロメトリーを行い， 術前値と比較した.

䫓部硬変 : 乳房切断術を受ける患者に, 第 7 跤椎で硬 麻を行らと, 第 4 頚䯣から第 7 胸㭪道までの無痛が得られ る.このとき， $\dot{V}_{\mathrm{E}}$ は25\%減少する，呼吸数に変化がな
く、VTが減少するためである. $\mathrm{PaO}_{2}$ は $9 \%$ 減少し, $\mathrm{Paco}_{2}$ は3\%增加する.また IC は28\%減少する。 $\mathrm{FEV}_{1,0}$ は25\%, MMF は23\%減少する。頝部硬麻では 安静換気のみならず，最大換気もかなり抑制される。

胸部硬麻: 胆哄摘出術を受ける患者に, 第12胸椎で硬 麻を行らと，第 6 胸㖪から第 4 腰哊までの無痛が得られ る.このとき, $\mathrm{VE}$ は24\%減少する。これはVT の減少 によるものである. $\mathrm{Pao}_{2}$ は7\%減少する. IC と VCは $13 \%$ 減少し，ERV む20\%減少する，FEV 1.0 は11\%。, MMF は22\%減少する.胸部硬麻でる安静換気は抑制 されるが，その程度は䅡部硬麻より軽い. 最大換気の抑 制は䫓部硬麻より明らかに少ない。

頝部および胸部硬麻で呼吸は抑制されるが, 頝部硬麻 では最大換気の抑制が著しいので注意を用する。

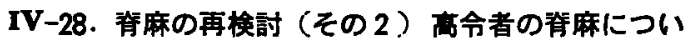
$\tau$

\section{日下部病院 日下部輝夫, 小河原当元 舟波 誠, 鈴木 親良 \\ 東京遁信病院 北原 哲夫}

私共は最近 3 年間に 60 歳以上の高路者の腹部手術を脊 麻下に手術したので，その結果を報告する。

症例は上腹部手術 111 例を含めて176例，その中には消 化管穿孔，出血，イレウス等の緊急手術例む含まれる.

痏麻の方法は前回にも述べた北原式に基き，手術台を 水平，患者を患側々臥位，殿部に腰枕を入れて骨盤高位 とし，頭部には枕をあてがって頭部を高くして，注入部 位は $\mathrm{L}_{2 \sim 3}$ と決め, 高比重液（ネオペルカミン $\mathrm{S}$ ) を上 腹部手術では平均 $2.5 \mathrm{ml}$, 下腹部では $1.5 \mathrm{ml}$ 注入, 30 秒 を待って仰卧位に移す一定の方式に従い，麻疸高はそれ ぞれ平均， $\mathrm{D}_{5-6}, \mathrm{D}_{7 \sim 8}$ であった。

春麻に際し最む留意すべきことは血压と呼吸対策であ るが, 高血圧の患者には術前昇王剤は投与せず, 脊麻後 血圧が下降すれば昇圧剤を静注, 更に $\mathrm{O}_{2}$ 吸入る併用す る、稀にみられる超高位瓷席による呼吸抑制には $\mathrm{O}_{2}$ を 投与して麻㾇の回復を待つことにより手術に支障を来し た症例は経験しない。

危惧される肺合併症は 1 例もなく，喀痰の増量する例 には気管粘溶解郕，ネブライザーにて対処した。

以上高龄者の腹部手術に際して春麻は，意識があると いらことが大きな利点であり, 更に肺合併症が少い, 出 血が少い，肝腎への影響が殆んどない等多くの利点があ り，再検討の必要があると結論する.

IV-29. 上腹部開腹術後低酸美血症に対する麻醉方法 


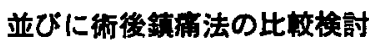

和歌山医大消化器外科

○橋本 雅夫, 河野 暢之, 勝見 正治 和歌山医大麻醉科

木下 達之，西本 憲生，上山 英明 上腹部開腹術後低酸素血症は無気肺や換気血流比の不 均等分布が主因とされその背景に airway closure が原 因と考えられている.この低酸素血症の進行に，年龄， 手術部位，麻酶法，術前上り存在する肺病変，術後疼痛 が影響するよいわれている．今回我々は上腹部手術患者 を対象とし，術前において，CC，FRC，動脈血ガス分析 值を湘定し，術前呼吸機能評価を行い，GOF K上る麻 醉及び術後鎮痛剂として Pethizine or Pentazocine を 投与した群と持続硬膜外麻醉を手術時及び街後疼痛管理 として用いた 2 群に分け, 術前, 術後1.3.5.7.日におい て, $\mathrm{PaO}_{2}$ を測定し, 術前 $\mathrm{CC} / \mathrm{FRC}$ と $\mathrm{PaO}_{2}$ を対比さ せ麻酔法及び術後鎮痛法の違いに上る術後低酸素血症に 対する影響を比較検討した，結果として術後におるける $\mathrm{PaO}_{2}$ 值において両群間で有意の差はなかった。また術 後における $\mathrm{PaO}_{2}$ の最低值と術前 $\mathrm{CC} / \mathrm{FRC}$ は全麻群で 有意の負の相関が得られた。一方硬麻群では有意の負の 相関が得られなかったが，これは硬麻群で CC/FRCの 高いものでも術後 $\mathrm{PaO}_{2}$ の低下の程度の少い症例が認め られたためと考える. 又, 術前 $\mathrm{PaO}_{2}$ 上り，術後におけ る最低 $\mathrm{PaO}_{2}$ 值への低下度は GOF 群での低下度は平均 $23.84 \pm 8.92 \%$ ，硬麻群では平均 $15.90 \pm 10.09 \%$ であっ たが統計学的には有意な差はなかった。結論として, 術 後低酸素血症の重症度は CC/FRC に上り予湘され，ま た術中から術後にわたる硬膜外麻醉はこの重症度を一部 軽減すると考える。

\section{座長のまとめ}

古川 幸道

このセクションは演題24から29まで麻醉に関する演題 6 題であった。

24 ：は東京慈恵医大麻醉科，根津武彦氏の「経口投与 による前投楽の評価」についてであった．最近筋肉内注 射の整害が社会問題としてとらえられている折柄 minor tranquilizer 法 Atropine を前投薬として経口的に与兄 ても十分な効果が得られるとのことであった。これに対 し，山口大第 1 外科の倉田悟氏は小児の場合，呕吐ある いは，のまない場合があるから筋注の方が確実である。 又, 座長より，小児の飲み易いシロップと，飲みたがら ないシャッブがあるが，どのよらなシロッブ基㓮を使用 しているか追加，質問があった. Diazepam のシロップ
を使用しているよらだが，将来より効果が確実でかつ組 織障害を起さない投与方法が考えられてしかるべきであ ろう.

25 : は札医大：高橋長雄氏の「笑気，酸素混合ガスの 臨床応用について，市敗の笑気酸素混合ガスを小手術に 単独あるいは NLA と併用し, Hangover が少ない，更 に循環系の心拍出量がふえ，全末梢血管抵抗を上げるの をみ，笑気の中权，血管系への作用によるとした．憼恵 医大の小林健一氏ょり術後鎮痛薬をどの程度節減できた かとの質問にベンタソミンの本数が半分にへったといら ことであった．麻醉の単純化を机らっているが，呼吸す ジマレードフロー・タイプより，ハックとマスクで補助 するように変えているよらで，システム全体の単純化， 安全性といら点で問題があるようである。

26 : 旭川医大麻酔科藤原慎司氏は「整形外科手術汶 する低血王麻醉の応用」について GOF 麻醉に trimethaphan を使用した例が最す出血量が少なかったと報告 した.これに対し，手術時間はどれだけ短縮されたかと の質問があったが，反って時間ののびている例るあり時 間的には有意差はないとのことであった。

27 ：札医大麻醉科：高崎真弓氏の「顥部打よび胸部硬 膜外麻醉の呼吸への影響」で麻醉総数の $1 / 4$ を硬麻で行 っており，上肢から下肢にいたるまで広範囲の麻醉が得 られるが，換気は20\%位抑制されるので，この程度を知 って批ぐきであるとの報告があった。

28：日下部病院の 日下部辉夫氏から「沗麻の再検討 （その 2）高龄者の春麻について」，60歳以上の高龄者 に执いても春麻は安全であるとして再愉討する必要があ ると報告があった．これに対し，慈恵医大小林健一氏， 札医大高橋長雄氏，山口大第一外科合田悟氏，札医大高 崎真弓氏らから春䀁の得失，意識の有無の得失などにつ いて活発な論㦈があった．単に麻醉方法の問題でなく， 患者の管理の方法による差違が大きいので，一概にクリ フカットすることは難しかろう。

29 ：和歌山医大消化器外科：橋本雅夫氏から「上腹部 開腹術後低酸素血症に対する麻醉方法並びに術後镇痛方 法の比較検討」について硬膜外麻醉を手衍時及び街後鎮 痛に用いた方か：GOF，鎮痛剂による方上り，術後低酸 素血症の症状を軽隇するとし，又，これは CC/FRC よ り予測されるとしていた。これも患者の管理方法, 又, その技術が予後を大きく左右すると考えられる。

活発な討論が行なわれたにあ拘らず，予定時間内に全 て終了することができたことは会員のご協力によること 
多大であると感謝します。

呼吸管理・その他 (IV-30～34) 坐長 高标 長雄 IV-30. 呼吸管理における肺外因子について 大阪大学特殊救急部

岡田 芳明，大橋 教良

寒川 昌明, 杉本 洒

外僖やショック後にしばしば呼吸不全 (ARDS) に陷 入ることはよく知られており，その成因についてもいく 加が指摘されている，病初期には換気/血流比不均等 の関与が認められるが，進行するに従い解剖学的シャン 卜，無気肺，抎散障害，換気/血流比不均等など全てを 含めた機能的シャント增加が中心となる。これら ARDS に対してレスピレーターを中心とした呼吸管理が行われ ているが，いずれる呼吸系に対するもので，これと不可 分の関係にある循環・代謝等に注目した研究は少なく， わずが PEEP に拈いて酸素輸送を最大にする best PEEP’ の概念が示されているに過ぎない，演者らは ARDS の病態の中心が上述の機能的シャントであること を Respiratory Index とシャント率の関係より明らかに した.

さらK, 吸入気酸素瀑度 $\left(\mathrm{FrO}_{2}\right), \mathrm{Hb}$ 量, シャント 率をパラメーターとしたノモグラムを作成し，一定のシ ヤント率で $\mathrm{FrO}_{2}$ を変えた際の $\mathrm{PaO}_{2}$ を予测すること を可能にした，一方，このノモグラムを症例について 领討すると, 予測值 $(y)$, 実測值 $(x)$ との間には $y=$ $0.973 x+6.6(r=0.967 n=83)$ となる 回帰一次式で 示される正の相関関係が得られ，機能的シャントが病態 の中心であることを裹付けるとともに， $\mathrm{FrO}_{2}$ を変えた 祭の $\mathrm{PaO}_{2}$ を予测することが出来ること， $\mathrm{FrO}_{2}, \mathrm{Hb}$ 量 からッャント率を得ることが出来る点で有用であること が示された。

また，等しいシャント率で，呼吸管理以外の 因子が $\mathrm{PaO}_{2}$ K及注す影響を検討し，心拍出量増加，酸素消費 量減少，へモグロビン量増加がいずれる $\mathrm{PaO}_{2}$ を上昇 させるすのであることを指摘し，併せて，貧血の補正 例，低体温による酸素消費量减少例に見られた $\mathrm{PaO}_{2}$ の 変動を呈示した。

IV-31. 外的息者における呼吸管理（特に PEEP）中 の V-v, P-V 曲線について

大阪大学特殊救急部

○岩谷 昭美, 岡田 芳明

島崎 修次, 黒岩 宏

現在，臨床上肺機能の変化は，血液ガス分析に頼ると
ころが多い，そして極度の呼吸不全患者の $\mathrm{PaO}_{2}$ を上 并させる目的では，PEEP が多用されている．今回， 我々は PEEP の際に，呼吸循環動態に及ぼす影簍を蹦 床例に打いて測定し，抢の怙のの相関について検討した ので報告した。

方法：調節呼吸を受けている重度呼吸不全患者を対象 に,オート，スパイロメーターを人工呼吸器回路内に接 続し,差压トランスジューサーを使用して気道内压と，食 道内压の圧差をとり，一回換気量とを X-Y レコーダー で記録し，Compliance を測定した．同時に Swan-Ganz カテーテルを肺動脈に挿入し，色素希稀法にて測定し， 動脈血，混合静脈血のガス分析を行った。さらに呼気終 末压を段階的に $0,5,10,15 \mathrm{cmH}_{2} \mathrm{O}$ と上异させて，各 PEEP での呼吸循環動態の変化を見た。

結果および考案

Flow-Volume 曲線は，自発呼吸時の 努力呼気曲線 と 違って診断的価値は認めなかった。全肺, 肺 Compliance とも，PEEP の上昇に従って低下した. PEEPに よりシャントが減少し, 改善した例もあったが, 逆にシ +ントが増加し $\mathrm{PaO}_{2}$ が低下した例もあった。

シャント率，隇少群と上昇群に分類し分析すると， $\mathrm{O}_{2}$-transport は, シャント減少群では低下著明例が多く, シャント上昇群では軽度の低下を示した．それは，心拍 出量の影響をそのまま受けたためである。

本来，呼吸管理の目的は，末梢各組織の酸素化である が, 今回の研究で, シャントは減少し, $\mathrm{PaO}_{2}$ の上昇 は認めた例でも， $\mathrm{O}_{2}$-transport が低下した例もあった。 だから，単に $\mathrm{PaO}_{2}$ を上げる目的で PEEP をかけるの は危険であり, 十分なモニターのむとに PEEP の設定 を行らべきすのと考える。

\section{IV-32. 肺性心を併発した特発性側棌症の 1 例} 東北大学医学部麻醉科

○黒田 直明, 吉成 道夫, 佐藤 光男

側弯症は, 胸廓の变形の故に肺の拘束性障害をきたす 可能性はあるか，臨床上問題となることは少ない，最近 我々は，乳児性特発性側弯症患者が術前高度の換気障害 から肺性心を併発したため，集中治療部において敩重な 呼吸・循環管理を行いながら手術を施行し，その後良好 な経過をたどっている一症例を経験した，その概要を報 告するとともに，側弯症患者の術前状態の評価について 若干の考察を加壳た。

患者は15歳の女児で，発症以来保存的潦法が 無効の ため，手術目的で某病院に入院した。入院時，胸椎右 
凸 $137^{\circ}$ の側弯変形および $98^{\circ}$ の 後弯変形があり, 肺活量 $600 \mathrm{cc}$ ，\%肺活量22\%であった．入院後の経過観察中に， 肺性心から急性 $\mathrm{CO}_{2}$ narcosis に陥ったため, 東北大学 病院集中治療部に緊急収容した. そして，経鼻捙管・人 工呼吸器による呼吸管理, ジギタリス剂投与による循環 管理, 経管栄荃等厳重な 全身管理を 行いながら, Halo-

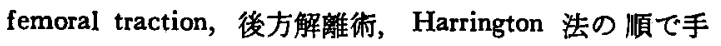
術を施行した。この間，心不全，肺炎，ジギタリス 毒, 人工呼吸器からの離脱の問題等多くの困難があった が，幸いにも乗りきることができ，入室後44日目に転院 した.

本症例の経験扎よび我々が経験した側弯症患者の検討 の結果, 側弯症患者の術前の心肺機能を把握する一つの スクリーニングの方法を考兄てみた。まず肺活量 $1000 \mathrm{cc}$ 以下，\%肺活量30\%以下をチェックする，これに該当 する患者には血液ガス分析を行い， $\mathrm{PaO}_{2} 50$ torr 以下上 $\mathrm{PaCO}_{2}$ 50torr 以上をチェックする. 臨床所見では浮腫, cyanosis, 肝腫大，呼吸困難等をみる，また，心電図か ら肺性 $\mathbf{P}$ の有無を判続する．以上に該当する患者には， 厳重な呼吸・循環管理を前提として対処する.

本症例のように極めて重篤な場合でる，厳重な管理を 行える施設に収容し，綿密な治療計画をたてて手術を行 えば，良い結果を得る可能性があると考える。

IV-33. 衍後長期に亘り人工呼吸器による管理を要し た症例の検討

昭和大学外科

$\begin{array}{rrrr}\text { O道端 哲郎, 高場 } & \text { 利博, 舟木 } & \text { 正明 } \\ \text { 四谷 敏朗, 松田 賢, 太田 } \\ \text { 石井 宏 }\end{array}$

我々の教室で, 昭和50年 1 月より51年12月までの 2 年 間術後人工呼吸を行った症例は42例；この間の手術総数 は, 1245例, 内いわゆる major sugery は, 662例で, 呼吸器使用例は major Sugery の6.3\%であった，術直 後より人工呼吸を行った症例は31例あり, 開心術, Poor risk 症例の呼吸及び循環不全に対し予防的に使用したも のが多く，18例は3 日以内に離脱出来，死亡率は26\%で あった. 術後 1 日以上経過して使用した症例は全例死亡 した. 使用期間は，最短 6 時間から最長67日で平均8.8 日，10日以内の使用例の死亡率は26\%であるのに対し， 10日以上の使用例では67\%と高率であった．10日以上の 長期使用例12例についてみると，術直後から使用した症 例 7 例は，全例心血管手術で，誘因として 6 例が LOS， 1 例が出血であり，心手術例 7 例は全て LOS を誘因
として使用された：腹部手術 4 例は， shock に誘因した と考えられる急性督不全及び術後出血に上る呼吸不全の 為使用され, 全例が急性腎不全で死亡した. 呼吸器使用 期間中に併発した肺合併症は，肺炎無気肺，肺出血，な どであったが，短期使用例では30例中 6 例 (18\%)，長 期使用例では12例中10例 $(87 \%)$ と高頻度の発生をみ た. 今回の検討では，術後長期人工呼吸を要する症例 は, 心手術後の LOS 腹部手術後の shock, 急性腎不全 が多く，これらは不幸な転㷌をとる例が少なくない．人 工呼吸は, これらの予防改善に有効と考えられ, LOS, 急性腎不全が照念される重症心手術, 出血例に対し, 予 防的に早期から使用は有効上考えられた. 又, 人工呼吸 期間中の肺合併症予防の重要性も示された.

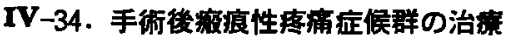

\section{北大麻酔科 後藤 康之, 佐々木和郎}

五十嵐 大, 古川 幸道

手術や外傷あるいは火傷後に生じた症痕が器質化され るには，相当に長い年月を要し，ここから交感神経を介 寸る刺激が送られて，疼痛と共に血管孪縮，チアノー ゼ，皮ふの萎縮などの交感神経立進症状を呈する場合が あり，これを痗痕性疼痛症候群と称している. われわれ はこれまでに手術後に生じた18例を経験しており，その 概要ならびに治療につきのべる.

18例中14例までが開胸手術後に生じたるので，他は泌 尿器科手術あるいは椎弓切除後に発生している.多くは 2 カ月以内に疼痛を生じ，しか子術後間むなくより疼痛 の持続するるのが大半であるが，1〜2年を経てから本 症候群を示した例るみられる。

診断としては，洀痕部を中心とした疼痛と，その近く に痛みの trigger point の存在することでありこれら の部位へ少量の局所麻酔薬を注入して疼痛が緩解するこ とによりたしかめられる。

治療法としては局所麻酔薬を用いて

(1) 局所浸潤麻酔

(2) 交感神経ブロック

（3）肋間神経などのブロック

(4) 硬膜外プロック

の順に適宜行い, 效果が不十分の場合には神経破壊剤の 使用も考虑される．またハリ麻䣲あるいはハリ治療の効 果も報告されている。

18例中 2 例は難治性であり，その中の 1 例は激痛が治 らぬため, 最初の疼痛発現後 2 年目に, 再度手術創を開 いたところ，皮下から笳肉および胸膜へかけて硝子化し 
た瘿痕組織と化した部分がみられ，組織学的所見では， その中に血管あるいは神経が埋っていた．したがって手 術操作す，本症候群の発生と関連し，しか子術後長期間 にわたる疼痛をるたらす一因となるるのと思われる。

\section{座最のまとめ}

高橋 長雄

IV-30大阪大学特殊救急部の岡田芳明氏らは ARDS の病態の中心と考えた肺内シャントを基礎としたノモグ ラムを作成し，このノモグラムの有用性を臨床例につい て検討した．外傷やショック後に楩る ARDS の病態に 対して呼吸管理に加えて心拍出量増加，酸素消費量抑 制, へモグロビン量增加などのための処膡の重要性を述 ベた。ノモグラム作成の基礎について帝京大学の岡田和 夫氏との間に discusion が行われた。

IV-31 同しく大阪大学特殊救急部の岩谷昭美氏 は，外偤患者に対する PEEP の際の $\dot{V}-V, P-V$ 曲線を 検討し, PEEP 王と肺-compliance, 全肺-compliance, 心拍出量, $\mathrm{P}_{\bar{V}} \mathrm{O}_{2}$ の間に正の相関があることをみ，これ らの諸量は $\mathrm{O}_{2}$-transport を知る指標になりらると述べ た. 対象とした症例について“best PEEP”はどらなっ ていたかとの札幌医大高橋長雄の質問に対 し, PEEP $=0$ との答が出された.

IV-32 東北大学麻酔科の黒田直明氏らは, 乳児性特 発性側弯症患者（側弯角 $137^{\circ}$ ) 飞扮きた高度の肺性心に 対して術前, 術後に行った呼吸・循環管理の成功例 (15 歳・女児)を発表した。手術は Halo-femoral traction, 後方解離術, Harrington 法の順で行われ，術前肺性心の 治療のため集中治療部に入室以来54日目に軽快退室した という.

IV-33 昭和大学外科 道端哲郎氏 らは, 昭和50, 51 年の 2 年間に, 術後種々術後種々の理由で人工呼吸器を 䒾着した42例について梳計分析を行った. 開心術後の18 例, その他の手術後の 8 例は術後 3 日以内に人工呼吸器 からの離脱に成功したが，12例は10日以上の装着を必要 とした. 死亡例は15例. 山口大学倉田快氏から, 術後24 時間たって人工呼吸器につないだ全症例死亡の理由が質 問されたのに対し，上り早期の装着が救命率を向上させ えたかるしれないとの反省が示された。札幌医大高橋長 雄の人工呼吸器装着の criteria は実際にどうしている かとの質問に対して，心葴手術後 LOS を若起すると思 われる症例に血液ガス所見を参考にしているとの答が出 されたが，術後血液ガス倹査をルーチン化し，一定の criteria で，粗漏なく低換気患者に呼吸管理のメリット を亭受させるべきるのであろう。
IV-34 北海道大学麻酔科 後藤康之氏らは, 手術後 の廐痕性疼痛症候群の18例を報告した．うち14例が開胸 手術後に発生し, 術後 $1 \sim 2$ 年して発症したものもあっ たという．2 例を除き症痕部扎よび附近のトリガー点に 局麻剂を浸潤すすることで，1 週間から20日間の治療で 治瘾せしめえた。神経ブロックの効果がなかった 2 例中 の 1 例に，洀痕組織の切除を行い治痣せしめえたとい 5. 大阪府立病院第 1 外科小野典郎氏, 帝京大学岡田和 夫氏からそれぞれ硬膜外のフェノール・ブロックと，疼 痛緩解と洀痕そのものの外観の変化などについてdiscussion が行われた．札幌医大高橋長雄の質問に応じ，今 回の18例中には心因性の因子の関与した例はないこと， causalgia 的な疼痛は症例により，または時期により認 められたと報した。

老人外科 (IV-35 40) 座長 过 秀男

\section{IV-35. 高命者開腹術後合併症の検討}

大阪府立病院第 1 外科

\begin{tabular}{|c|c|c|c|c|c|}
\hline ○前田 & 信証, & 小野 & 典郎, & 池㭭 & 雅成 \\
\hline 渡辺 & 洋敏, & 西村 & 正, & 岡田 & 康声 \\
\hline & 徹郎, & 角谷 & 㤟男, & 福井 & \\
\hline
\end{tabular}

\section{同 麻酔科 金 世栄 \\ 同 心診科 玉井 正彦}

1976年 4 月〜78年 3 月の 2 年間に経験した高龄者（65 歳以上) 開腹術総数は151例であり，その内，肺合併症 22例，縫合不全13例，心合併症 8 例, 肝障害 6 例, その 他計50例 $(33 \%)$ の術後合併症があり, 死亡例数は10例 であった．今回，我々は特に術後心合併症について検討 したか，その症例は心筋梗塞 3 例，重篤な不整脈 4 例， 急性心膜炎 1 例であり死亡例はなかった，術前の心肺機 能点数 (和歌山医大消化器外科教室の高龄者リスク点数 表による) では, 正常 ( $1 \sim 5$ 点) 128例中 $4.7 \%$, 異 常（6 点以上） 23 例中 $8.7 \%$ に心合併症を経験した。術 前心電図では正常87例中2.3\% K，異常64例中9.4\%に心 合併症が発生した. 異常例中 ST-T 変化高度の 4 例では 2 例に心合併症をみている。

心合併症 8 例についてみると，術前高血圧を伴らすの 3 例, 心電図河何らの虚血性変化を示するの 6 例, 手 術時間が 3 時間以上 5 例，出血 $1000 \mathrm{cc}$ 以上 5 例であっ た. 発症時期は 7 例が48時間以内であった。臨休症状で は，心筋梗塞の 3 例とす無痛性で，頻脈，不整脈血圧低 下拈よび心電図変化により発見されている。

以上より我々が採用した機能点数からは心合併症の術 
前予測は困難であったが，心電図の ST-T 変化高度例 扣よび調律伝導系異常例には允分な注意が心要であり， 術後心筋梗塞は定型的症状を呈しないものが多いことに 留意しなければならない，我くは術直後より3日間心電 図モニターを行ない早期の異常発見に心掛けている．現 在まで死亡例は経験しておらず，早期発見，早期治療に より，心合併症の重篤化を防止出来ると考えている.

\section{IV-36. 老人の手街に対する限界}

山口県厚生連周東総合病院外科

倉田 浩, 植木 幸一, 縄田 泰生
守田 知明, 兼行 俊博

過去 3 年間における70歳以上の 手術症例は137例で, 最高は90歳であった. 疾患別では悪性腫激が過半数を占 め, とくに胃癌は33例であった，入院死亡は26例で，衍 後30日以内の手術死亡は16例之高率であった。術後, 創 哆開を20例に，前立腺肥大に上る尿路感染を 4 例に認め たが死亡例はない，絴合不全を来した 5 例中 2 例が死亡 し，腎不全の 4 例では 3 例が死亡した。肺合併症を生じ た25例中 6 例が死亡し，この内 3 例は COLDに罡患し ていた. 肺合併症は発生率, 死亡率ともに高いのでその 予防，治療は老人外科のキーポイントの1つと言える. しかし術前の肺機能検査の成績と肺合併症の発生頻度に は相関なく，その予測は困難であった．長時間の手術が 予測される症例には swan-Ganz カテーテルを挿入し， 心拍出量, 肺動脈圧等を経時的に湘定し術後療法の指標 とした．術後 1 日又は 3 日目に心拍出量, 肺動脈王は高 値を示した。これは術中ならびに術後早期に組織内に移 行した水分が血管床に戻り，循環血液量が増加したこと が主因と思われる.又術後一日目には一回換気量は著明 に低下し，呼吸数は増加し，分時換気量は術前值を上 回ったこれは術後低酸素血症による Hypoxic hyperventilationである.この様な浅く速い呼吸パターンは肺 合併症発生の大きな因子となっている. 術後早期には過 剩輸夜を避け，酸素吸入，気道確保と十分な喀痰の排出 を企り，無気肺を予防するため，手術時間が 4 時間を越 えた 7 例と, 開胸の 4 例，術前肺機能異常を示した10例 に術後一昼夜に亘る人工呼吸を行なった，肺機能異常を 伴った 10 例中 7 例が肺合併症を併発せず順調に経過した ことは本法の有用性を物語るすのである.

以上, 高龆者の手術予後を左右する術後肺合併症の予 防策を中心に高路者手術の限界を検討した。

\section{IV-37，高令者手街例の臨床的镜祭} 小見川中央病院外科
大河原邦夫, 前嶋 清, 山崎 章郎 姬野 堆司，南波 美伸，小林 愿之 われわれは昭和 47 年 4 月から昭和53年 3 月までの 6 年 間に当院で施行した60歳以上185例の手術例について臨 床的観察を行ない，いささかの知見を得たので報告し た. 185例の男女比は $2 ; 1$ で男性に多く，60歳代120 例，70歳代59例，80歳代 6 例であった。疾患別に見ると 胃癌が最も多く，胃良性疾患，胆石症，虫垂炎等が比较 的多く見られた．術前の合併症としては，高血圧，肺合 併症，糖疗病等が多かった（185例中34例18.4\%) ᄂ かしながら術前の充分な管理により，手術を断念したも のはなかった．術前の胸部 X線では, 胸膜の肥厚,びま ん性あるいは局所的線状陰影，心電図では，ST.Tの 異常が多かった，術前の貧血および 低蛋白血症は，高 㱓になるにしたがい增加の㑯向を示した．術式では胃切 除，胆の5摘出術等が多くみられた。術後合併症は; 185例中53例28.6\%に何等かの合併症が認められた. 肝 障害が最も多く，耗合不全，イレウス，肺合併症が主な るのであった. 術後 1 カ月以内の手術死亡例を検討する と，60歳以上 185 例中 5 例，60歳末湠850例中 6 例で，高 踰になるにしたがい増加の傾向にあり，原因別では，出 血，耗合不全等が多かった．60歳以上では 5 例中 4 例が 緊急手術例であり，緊急手術例の場合に，手術時期の夕 イミングを含め, 術前術後管理の改善が, 今後の高龄者 手術の課題と思われる。

以上の観察により，高龄者の術後の合併症は，高度に 見られたが，手術成績は成人に比して大差なく，筇重な 術前術後の管理により高龄者でる良好な手術成續が得ら れるものと考える。

\section{IV-38. 高命開脑待例の㛟討}

岐阜歯科大学外科

野田 秀樹, 大沢 二郎, 䏱 勝文
有井 滋樹, 橋田 鿍平, 河野 有明
篠田 正昭, 村上 治朗

過去 5 年間に, 70 歳以上 高龄者の開腹術を166例释 験したがこれは全開腹術例の10\%にあたる。この他 Risk が覀く姑息手術すら断念した症例が11\%に認めら れた。疾患のうちわけは，胃癌37，大腸癌30, 肝䏣脺覀 性疾患 9 ，など覀性疾患が 81 例 (48.8\%), 良性胆道疾患 26，急性虫炎炎18，イレウス16，など 良性疾患が85例 (51.2\%)であった。死亡率は悪性疾患で16\%，良性疾患 で8.2\%，全体で12\%であった. 高㱓者の場合．急を要す る手術例が多く，36.8\%に緊急手術が行われてお゙りこ 
の㑯向は加龄と共に增加している．術前から原疾患の他 飞㢢存疾患を有することが多く $(69.3 \%)$ ，併存異常と しては, 循環器采合併症, 貧血, 低タンパク血症, 肝障 害, 肺合併症が多く，これらの異常のらち電解質異常, 低タンパク血症, 肝障害, 堅障害例では衍後合併症の発 生率, 死亡率共に高い値を示した. 又術後合併症は 48.8 \%にみられ，その死亡率は $24.7 \%$ に達した。合併症とし ては, 肺合併症 (16.3\%), 偱偯器系合併症 (15.7\%), 尿路感染症, 肝障害が多く, 特に前二者は発生率, 死亡 率共侅く，その他発生率こそ低いが高い死亡率を示す 合併症として，消化管出血，イレウス，腎不全があげら れ，これらの症例では半数以上が死亡している. 手術時 間との関係では，手術時間が長くなればそれだけ，合併 症発生率，死亡率も高くなっている．その他術前の呼吸 機能障害と合併症の間には関係が見出せなかったが，な 牰術前からの管理には注意を要すると思われた．以上， 高龄者手術にあたっては，迅速かつ正確な很前状態の把 握と改善が要求され，一度合併症が発生すると重第化の 偭向が強く，その予防と早期予知，早期処厧が第一七考 えられた。

\section{IV-39. 高令者手術成模の検討}

浜松赤十字病院外科

○松田 宏一，菊地 功次，我鋪 修二 森岡 暁, 森田 淳, 佳山 正男 近年平均寿命の延長に伴い，老人層の增加がみられ， 若壮年者之同様湔手衍行われる傾向にある，我々の施 設に颃いても高龄者の手術件数は漸增し，昭和48年から 52 年の 5 年間の手術総数 2464 中 70 歳以上の脳心肺を除く 一般腹部症例手術数は196例あり，全体の約 $8 \%$ を占め る. 今回その手術成績に険討を加えた. 疾患別には, 胃 癌70例, 大晹癌25例, 肝胆脺悪性疾患18例, 乳癌 2 例乞の 他悪性疾患 2 例, 良性胆道疾患 21 例, 各種ヘルニフ疾患 19例，胃良性疾患11例，イレウス 5 例，之の他良性疾患 12例であっ．更に主なるのを疾患別に検討すると，胃癌 は，全体の $18.9 \%$ を占め，手術死亡率 $5.7 \%$ ，大腸疾患 は，全体の $22.5 \%$ を占め，手術死亡率 $7.4 \%$ ，肝胆脺要 性疾患は，全体の53\%を占め 手術死亡率 $16.6 \%$ ，良性 胆道疾患恃全体の $13 \%$ で 手術死亡率 $4.7 \%$ ，良性胃疾患 は, 全体の3.6\%で手術死亡はなかった. 術前検査では, EKG 異常 焣機能低下 $9 \%$ にられた。術後合併症は，68.3\%にみ bれ，術後高血王 $33.6 \%$ ，肺合併症 $9 \%$ ，心合併症 7.6 $\%$ ，創部 $7.6 \%$ ，堅尿路系合併症 $4.6 \%$ ，䋖合不全 $3.0 \%$ ，
敗血症 $1.5 \%$ ，肝不全1.0\%であった。直接手術死亡例 12 例で，手術死亡率5.7\%であった．高龄者の手術は，術

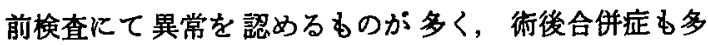
いが，行前管理にて資血，低蛋白電解質，腹水の補正， EKG 異常者に 対する適切な処盾, 術中術後に IPPB, ヘートモニター, ペースメーカー等を活用し，合併症を 早期に発見し，早期治潦することにより高龄者の手術 をより安全にし，成人に近い成積を期待出来るものと考 える。

\section{IV-40，老年者における術後精神障害}

東京都養育院付属病院外科

山城 守也, 中山夏太郎, 橋本 繁

野吕 俊夫, 日野 恭徳

東大第 1 外科 窪田 幸藏

（目的）老年者で術後に一過性のせん妄状態をみるこ とは稀ではない，一般，腹部手術の術前状態として，本 症発生の可能性を予知することは，手術適応の一因とし て重要である. その予測の可否，発生の予防策につき臨 㕅的検討を試みた。

（対象および方法）昭和52年 6 月から12月までの入院 手術73例について，1．術前の精神状態を精神科に伎類 しチェックした．2. 術後の精科状態をいくつかの異常 行動についてチェックし，1 週間の経過を観察した.さ らに最近の例について，術前後の脳波を測定し術前の判 断資料としての価值検討をはじめている．3．これらの 資料を年龄，手術唚襲，環境因子，慢性脳应候群，睡眠 障害，処置などの面から分析を試みた。

（結果）老年者の手術では，43\%に招いて，大手術例 については $51 \%$ に術後一過性のせん妄状態を発生する。

高龄，大唚蹵．救急手術程高率に発生する．また不眠を 訴えるものに多い，罢境因子としては，酸素テント，心 電図モニターの期間に差がみられたか，せん妄発生日平 均2.1日目といら点からみると，非発生群でる上まわる 日数で，その因果関倸は決め難いと思われた。点滴，導 尿カテ留置には差はみられなかった。

一般に発生群は明らかに高龄群に多発し, 高龄といら 予備力低下の因子が主体であるが，60歳代にもみられ， また80歳代にみられないものる少数ながらある．脳波を とり同年代で，発生例と，非発生例をみると両者に差が みられるむのがあり，今後さらに検討する必要があると 考えられた。

発生の予防には，術後の疼痛を少くし，拘束する処置 をさけ，充分な睡眠がとれるよう配慮することが肝要で 
ある。

\section{座長のまとめ 辻 秀男}

近年，老人に対する手術の機会が增加しているが，老 人の手術に共通する種々の術前後の問題が提起された.

IV-35一-39までの演題は夫ィの施設に救ける老人手術 の経験が述べられた．調査対象としてはIVー37を除き70 藏以上をとっていて，老人外科の特殊性はこのあたりか らはじをるとみるのが大方の一致した意見かと思われ る.

術前の問題点としては，高血圧，EKG 異常のほか糖 尿病，気管支炎，貧血などを併有するものは甚た高年 （IV36，38）である. したがって術後合併症の発生率も 30\%（IV37)，49\%（IV38）と高く，その主なるのは肺 合併症，腎不全などと老人の特殊性が示された。しかし EKG 異常など循環器病変が術前高年に認められたにか かわらず，心合併症に上る死亡は演者らが言及された限 りでは0であった。 そのかわり出血, 䋖合不全,イレウ スなど術前状態とは無関係とも思われる死亡が注目され た $(37,38)$. 出血, 释合不全など 手術手技上の問題が 大きいことはいらまであないが，老年者とは異りこれら が直ちに死亡に結びつくところに老人の特殊性があり， このことは術前合併病変の併有率が高いことと大いに関 係があると思われる.イレウスや腎不全による死亡る同 様で，老人の手術成績の向上にはまず手術手技の確実 と，侵襲性を少くすることが重要と思われる．

これに比較すると心異常に対しては術前術後を通じて
注意が厸われるためか，死亡はむしろ少ない（35，39）。 しかし討論では術中の 血圧下降や輸血量がとり上げら れ，術中循環管理の 重要性が 指摘されたよ5に思われ る.

肺合併症は老人では最す重要であり $(36,38)$, 約20 \%といら死亡率が示された。これを訹前肺機能検查で予 知することは困難と思われるので (36)，予防と早期発 見, 早期治療飞努力を凍らことが肝要であるう．治療飞 ついて気管切開の適応が問題になった．補助呼吸，酸素 療法を含めて適応決定の指標を討論できなかったのは残 念であった。

老人の緊急手術成績が不良である点については36でだ け指摘があったが，これは老人手術における今後の重要 問題と思われる. 待期手術の手術成績は年々向上してお り，老人手術の問題点は両者をわけて論ずるのが適当と 思われる。

IV40では，老年手術患者の精神障害が検討され興味深 く思われた，術前の性格变化，意志柾通性は手術適底決 定の重要な指標とされており，精神障害以外の合併症と む関係が深いよ5に思われる.討論では全身的血行障害 との関連性が示咬されたが，最も老人外科的な問題と思 われた。

以上，各演者は老人といらリスク不良群の患者ととり 組んでそれぞれに努力しておられ，その熱意に敬意を表 したい. 問題は複雜多岐に亘るので，益々の御精進を期 待する次第である。

\section{第V会場 午前の部}

胃痓 I $(V-1 \sim 4)$ 夾長 間岛進

V-1. 細胞性免疫能よりみた胃密リンパ節転移の検討 東京女子医科大学消化器病センター外科

小川 健治, 三上 直文, 矢川 裕一

大谷 洋一, 鈴木 博孝, 柇原 宣

癌腫の根治手術として，所属リンパ節を含めた広範な 黁清手術が今日広く行われている。一方, その所属リン パ節は担癌宿主における生体防御機構の一環をなし，抗 睡場性発現の場であることも明らかにされている。この 上5な瘇湯免疫学的観点からみれば，所属りンバ節も含 めて切除する㡲清手術に, 癌治療上，意義が認められる のであろらか．この問題を解明する目的で，廓清手術が なされた胃癌20症例およびその所属リンパ節361個を対 象として検索した。リンパ節は手術時, 無菌的に摘出
し，半切，その一半よりリンパ球浮遊液を作製， $\mathrm{T}$ 細胞 比，PHA-M に上る幼若化率を湘定し所属リンパ節細胞 性免疫能の指標とした。 また他の一半から病理組織学的 なリンハ節転移の有無について検索した。

結果：1),リンハ球の $\mathrm{T}$ 細胞活性を指摽としてみた胃 癌所属リンパ節の細胞免疫能は, 癌腫の進行度や深達度 が進むにしたがい低下する．2）廊清用リンパ節群別に みれば，転移の有無にかかわらず，第 3 群といら遠位り ンパ節に比較して，第 1 ，第 2 群といら近位リンパ節の 細胞性免疫能は低下している，3）同一群のリンパ節で あれば，転移陰性リンハ節に比較して，陽性リンバ節の 細胞性免疫能は低下している。

以上の結果より，術中に転移リンバ節を充分に識別で きない現在におい、ては，少なくとす細胞性免度能の低下 